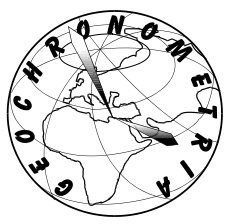

Conference Proceedings of the $12^{\text {th }}$ International Conference "Methods of Absolute Chronology" May 11-13 $3^{\text {th }}, 2016$, Gliwice-Paniówki, Poland

\title{
CLIMATIC SIGNALS IN TREE-RING WIDTH AND STABLE ISOTOPES COMPOSITION OF PINUS SYLVESTRIS L. GROWING IN THE INDUSTRIALIZED AREA NEARBY KĘDZIERZYN-KOŹLE
}

\author{
BARBARA SENSULA ${ }^{1}$ and SŁAWOMIR WILCZYŃSKI ${ }^{2}$ \\ ${ }^{1}$ Silesian University of Technology, Institute of Physics - Centre for Science and Education, Konarskiego 22B, 44-100 Gliwice, Poland \\ ${ }^{2}$ Department of Forest Protection, Entomology and Forest Climatology, University of Agriculture in Krakow,
} Al. 29Listopada 46, 31-425 Kraków, Poland

Received 20 May 2016

Accepted 9 May 2017

\begin{abstract}
The main aims of these studies were dendrochronological and mass spectrometric analysis of the impact of climate on tree rings width and stable isotopes composition in pine (Pinus sylvestris L.). The conifers were growing in the vicinity of chemical and nitrogen factories in Kędzierzyn-Koźle (Poland) in the period of time from 1920s to 2012 AD. The combined usage of tree ring width and isotopic composition data provides historic records of the environment changes. These data allows identifying the behavior adaptation of pine growing under pollution stress to climate changes. The incremental rhythm of the studied pine populations was not identical, probably due to their different sensitivities to some climatic factors. This study evidences that the isotopic records in tree-rings $\alpha$-cellulose may be sensitive bio-indicators of the way that the components of air and water may be changed by the trees in response to the climate changes and anthropogenic effects. The water use efficiency may be strongly correlated with variability of the surface temperature that may be due to increase of $\mathrm{CO}_{2}$ emission.
\end{abstract}

Keywords: pine, climate, tree rings width, stable isotopes, water use efficiency.

\section{INTRODUCTION}

In our studies, we used tree-rings as indirect archives of climate changes and environmental pollution in $20^{\text {th }}$ and $21^{\text {st }}$ century. In Poland the highest levels of pollutants were recorded in 1980s (Boden et al., 2016). Since the 1980 s, a few environmental projects have been implemented in most factories in Poland, similarly to many countries in Europe. Since the 1990s a decrease of pollu-

Corresponding author: B. Sensuła e-mail: barbara.sensula@polsl.pl tants emission has been noted. The observed anthropogenic impact on the environment causes changes in the elemental composition of the atmosphere and the biosphere. Trees intercept and absorb air from the atmosphere and they can be used as sensitive bio-indicators of ecosystem changes. Scots pine has been used in biomonitoring studies, because this species is sensitive to climate and the anthropogenic effect (Schweingruber, 1996; De Vries et al., 2000; Sensuła et al., 2011 a, 2011b; Sensuła and Pazdur, 2013a, 2013b). Scientific literature reviews show, that the industrial pollutants usually have a negative impact on vitality and annual radial growth of 
trees. The strength of the negative impact of pollution on trees can be varied in space and depends on the habitat conditions and distance from the source of pollution, directions of prevailing winds (Wilczyński, 2006; Danek, 2007; Elling et al., 2009; Malik et al., 2012). The trees, growing under stress of the pollutants, reduce their radial growth and height growth (Kienast, 1985, Schweingruber, 1986; Krąpiec and Szychowska-Krapiec, 2001; Danek, 2007; Elling et al., 2009; Malik et al., 2012; Crecente-Campo et al., 2010). Also the differences in the similarity of radial growth response of pines to individual climate factors (temperature, sunshine, precipitation, air humidity) has been observed (for example Sensula et al., 2015a, 2015b).

The climate changes and industrial pollutant emissions occur during physiological processes responsible for plant growth and also can influence stable isotope composition of wood and its components (Craig, 1954; Farquhar and Lloyd, 1993; McCarroll and Loader, 2004; Sensuła, 2015). There has been much discussion about the biological effects of pollutant pressure on trees, which concerned yearly variation of stable isotope concentration in tree rings and needles (Craig, 1954; Farquhar and Lloyd, 1993; Field et al., 1995; McCarroll and Loader, 2004; Pazdur et al., 2007, 2013; Keeling et al., 2010; Parn and Madre, 2011; Sensuła and Pazdur 2013a, 2013b; Battipaglia et al., 2014; Saurer et al., 2014; Sensuła, 2016a, 2016b). The isotopic records in tree-rings are sensitive bio-indicators of the way that the components of air and water have been changed by the trees in response to the environments in which they are grown (Craig, 1954; Farquhar and Lloyd, 1993; McCarroll and Loader, 2004; Sensuła, 2015). It is possible to estimate from the isotope response, whether a plant reacts more strongly on the supply side (stomata) or the demand side (biochemical) of photosynthesis (Scheidegger et al., 2000; Farquhar and Lloyd, 1993). Previous studies have shown changes in climate signal in stable isotope composition of $\alpha$ cellulose of tree ring cellulose as well as deviant trends between $\delta^{13} \mathrm{C}$ and $\delta^{18} \mathrm{O}$ series caused by pollution in different parts of Europe during the $20^{\text {th }}$ century (Boettger $e t$ al., 2014; Sensuła, 2016a).

According to the NOAA (2016), the average global atmospheric $\mathrm{CO}_{2}$ concentration has risen from $331 \mathrm{ppm}$ in 1975 to $393 \mathrm{ppm}$ in 2012. The observed anthropogenic impact on the carbon cycle is mainly related to various global industrial activities (Boden et al., 2016) that have caused changes in the isotopic composition of carbon in global air atmosphere (Martin et al., 1988, Ferrio et al., 2003; Keeling et al., 2010; Pazdur et al., 2013). Elevated $\mathrm{CO}_{2}$ significantly decreases $\delta^{13} \mathrm{C}$ in the air (Fig. 1). The $\delta^{13} \mathrm{C}$ present in air is about $-8.3 \%$. A depletion of $\delta^{13} \mathrm{C}$ values may be due to the global and regional effects of fossil fuel burning and it may be also due to emissions connected with local sources of pollution (inter alia industrial factories, vehicles, low stack emission of $\mathrm{CO}_{2}$ ).
The aim of our studies was to investigate the sensitivity of the pine populations to various climatic factors (such as the air temperature, the precipitation, the humidity and the sunshine duration) in the area influenced by the industrial pollution. The variation of the annual radial growth was used as an indicator of the tree's response to climate factors during the period of time since 19512012, when strong increase of industrial activities in the investigated area were observed. The sampling sites were located in different distance and in different geographical directions from industrial factories (Sensuła et al., 2015a, 2015b).

The mass spectrometric analysis of the carbon and oxygen stable isotope composition of cellulose extracted from the pine population growing in the most polluted site was complementary to dendrochronological studies. The isotopic composition of pine tree-rings was used to study the climatic changes in the industrialized area in the past to better understand future consequences of ecosystem changes (Schweingruber, 1996; De Vries et al., 2000; McCarroll and Loader, 2004; Pazdur et al., 2007, 2013; Sensuła et al., 2011a, 2011b; Sensuła and Pazdur, 2013a, 2013b; Sensuła, 2015). Combined measurement of carbon and oxygen isotopes ratio may give information about the changes in stomata conductance (gs) and changes in photosynthetic capacity $\left(\mathrm{A}_{\max }\right.$ - the average maximum net photosynthesis at ambient $\mathrm{CO}_{2}$ concentration under optimal environmental conditions) and indicate which factor responded more strongly (Farquhar and Lloyd, 1993; Scheidegger et al., 2000) to variation in the growth environment. According to Farquhar and Lloyd (1993) these changes can be also described by carbon isotope discrimination $\left(\Delta^{13} \mathrm{C}\right)$, which may be considered as a photosynthesis-weighted integrator of carbon supply and demand.

The objectives of this study were to analyze: (1) the record of climate changes and (2) the biological adaptation to pollution of pine growing nearby chemical and nitrogen factories in Kędzierzyn-Koźle during the period of industrial development and implementation of pro-

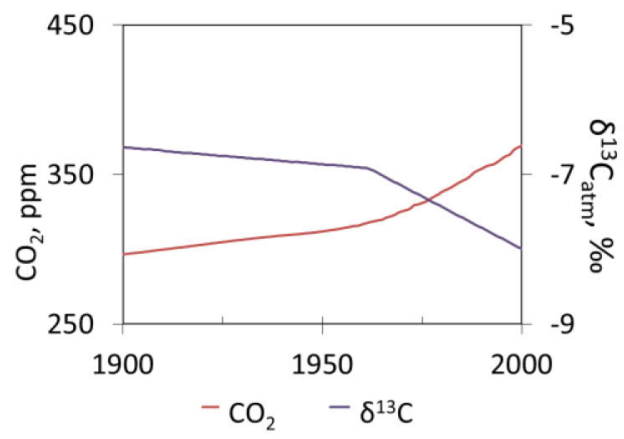

Fig. 1. Decrease of $\delta^{13} \mathrm{C}$ in the air due to increase of $\mathrm{CO}_{2}$ (according to Boden et al., 2016; McCarroll et al., 2009). 
ecological policy in Poland. There is still a lack of data concerning the environmental changes in the most industrialized part of Poland over the last century. In these studies, we determined the stable carbon and oxygen isotopes concentration in annual tree rings of pine growing in close proximity to chemical factories in Kędzierzyn-Koźle during the period of industrial development and implementation of pro-ecological policy in Poland.

\section{MATERIALS AND METHODS}

\section{Research area}

Kędzierzyn-Koźle $\left(50^{\circ} 20^{\prime} \mathrm{N} ; 18^{\circ} 13^{\prime} \mathrm{E}\right)$ is located near two factory complexes (Fig. 3): Blachownia Holding S.A. (previously named: Blachownia Chemical Factory), where chemical production began in 1941, and nitrogen factory Grupa Azoty ZAK (previously named: Zakłady Azotowe Kędzierzyn-Koźle, ZAK) where production started in 1954. In both factories, many different units and production facilities were constructed and added over a period of the last 60 years. Since the1980s, numerous projects dedicated to environmental protection were implemented in both factories. After many years of trying to minimize the negative impact of production processes on the environment, these factories were removed from the list of the most environmentally noxious companies. In 2004, the Waste Management Plan for the City of Kędzierzyn-Koźle set strategic objectives for 2015, inter alia: the introduction of the principles of "cleaner production". The companies operating in Kędzierzyn-Koźle are of strategic importance to the region and the country.

\section{Meteorological data}

The period from 1951 to $2012 \mathrm{AD}$ was characterised in the regional climate records by an annual average temperature of about $9^{\circ} \mathrm{C}$ (data range from 6.7 to $10.6^{\circ} \mathrm{C}$ ), and a mean annual sum of precipitation of around 610 $\mathrm{mm}$ (data range from 359 to $868 \mathrm{~mm} /$ year); mean annual number of sunshine hours is approx. 1530 (data range from 1108 to 1978), relative humidity around $80 \%$ (data range from 75 to $86 \%$ ). The lowest precipitation was observed between mid-1980s and mid-1990s (Fig. 2). The vegetative period begins in April and lasts until September. The meteorological data were obtained thanks to the Polish Institute of Meteorology and Water Management (IMGW-PIB). Temperature, humidity and precipitation data comes from the meteorological station in Opole, whereas sunshine data come from the meteorological station in Katowice.

\section{Samples and standardization process}

Scots pine (Pinus sylvestris L.) is a dominant species in the investigated area. For dendrochronological analysis, twenty trees were selected from each population (tree stands). The examined pines were healthy and grew in similar habitat conditions at different distances and directions from the industrial factories (Fig. 3).

All sites were classified as fresh mixed broadleaved forests. In order to avoid different dendroecological reaction of juvenile wood, an attempt was made to select pine stands aged between 80 (site A) and 100 years (sites C, B, $\mathrm{N}, \mathrm{S}$ and T) which is the felling age of Scots pine. The pine trees were dominant or co-dominant individuals.
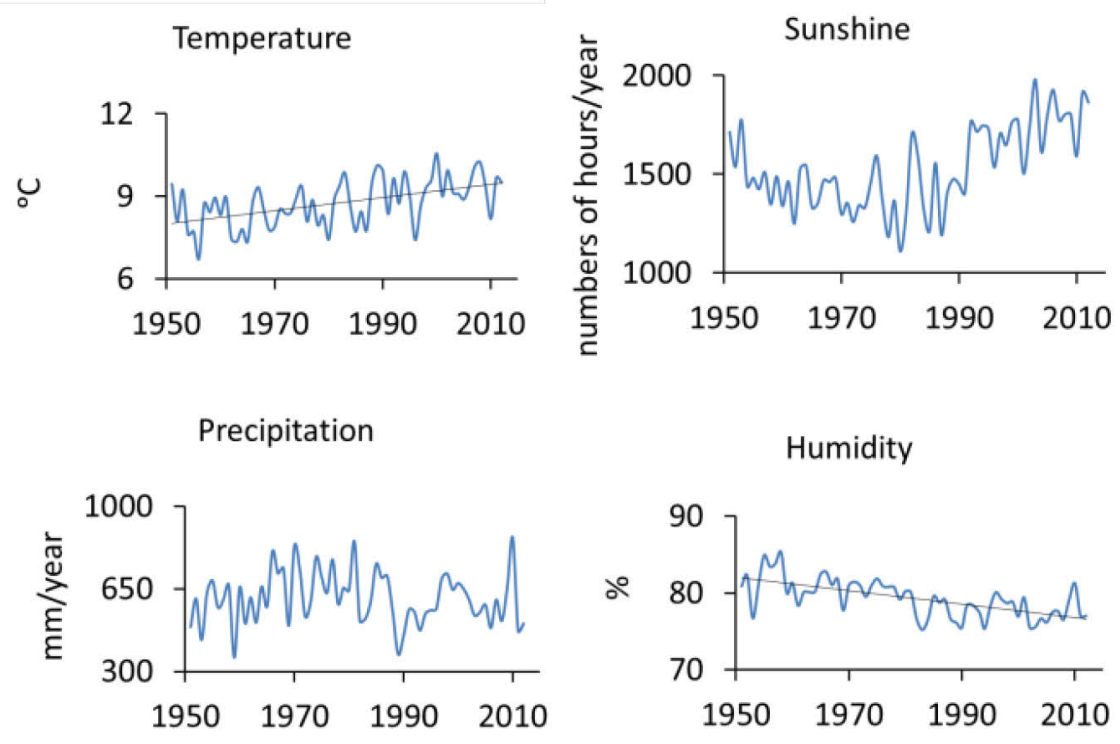

Fig. 2. Climate conditions (mean annual temperature, annual sunshine, annual total rainfall, and air relative humidity) in Opole (1951-2012). 


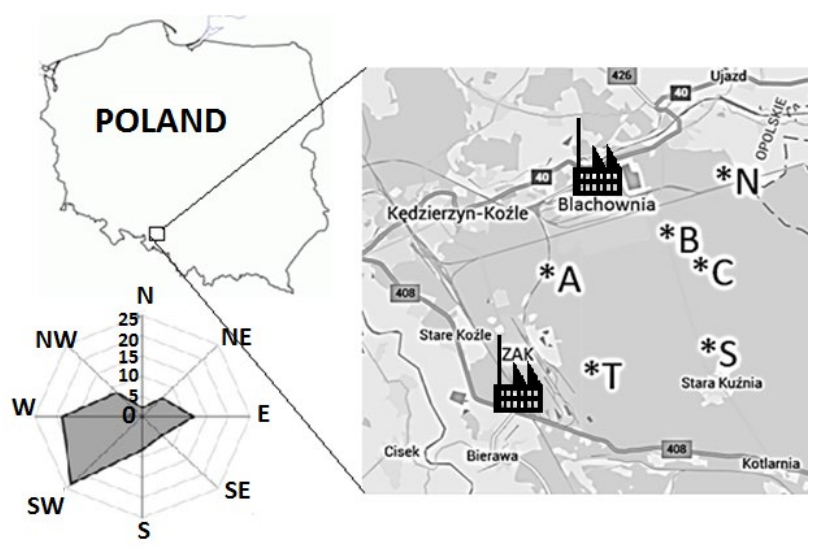

Fig. 3. Sampling sites $(A, B, C, N, S, T)$ in the vicinity of the nitrogen factory: Grupa Azoty ZAK (ZAK) and chemical factory Blachownia Holding S.A. - in the southem part of Poland; and dominant wind direction.

One increment core from each tree was taken at a height of $1.3 \mathrm{~m}$ above ground. Tree-ring widths were measured to the nearest $0.01 \mathrm{~mm}$. The tree-rings were dated and rechecked using the COFECHA program (Holmes, 1983). Each tree-ring width series was standardized to remove non-climatic trends due to age and growth effects. Therefore, in each year the annual sensitivity index $\left(\mathrm{s}_{\mathrm{i}}\right)$ was calculated according to the formula:

$\mathrm{S}_{\mathrm{i}}=2 \cdot\left(\mathrm{x}_{\mathrm{i}}-\mathrm{x}_{\mathrm{i}-1}\right) \cdot\left(\mathrm{x}_{\mathrm{i}}+\mathrm{x}_{\mathrm{i}-1}\right)^{-1}$

where $\mathrm{x}_{\mathrm{i}}$ is the tree-ring width in year $i$ (Douglas, 1920).

The mean change of the tree-ring width for the 19512012 period was evaluated by the mean sensitivity (MS). MS indicates interannual changes of the trees' sensitivity to climate factors (Fritts, 1976). The site sensitivity chronology was constructed on the basis of series sensitivity. The site sensitivity chronology exposed the short-term variance due to variation of climatic factors. The similarity of short-term incremental reactions of trees in each pine populations was evaluated by calculating the mean between-tree correlation $\left(\mathrm{r}_{\mathrm{bt}}\right)$. The calculated index EPS enables an assessment of the representativeness of the constructed site chronologies (Wigley et al., 1984).

\section{Ordination of the pine populations and climate- growth relationship}

The principal component analysis (PCA) was applied to identify the short-time factors affecting tree-ring widths. The identification of PC1 and PC2 was based on an analysis of the component scores. The variables $(n=52)$ were site sensitivity chronologies. The cluster analysis (CA) based on Ward's method and 1-r Pearson's distance has been used to analyse similarity of the response of each pine population to climate elements in the 1951-2012 period. The variables $(\mathrm{n}=52)$ were correlation coefficients between the site sensitivity chronologies and monthly temperature, precipitation, relative humidity and sunshine duration from the prior September to the current September. Response function analysis (Fritts, 1976; Holmes and Lough, 1999) was used to identify the climatic factors that determined the PC1 and PC2. These results were verified by analyzing the correlation between site sensitivity chronologies and the climate parameters.

\section{Isotopic measurements}

The analysed samples covered the period 1975-2012 AD. The $\alpha$-cellulose samples were extracted from increment cores of ten representative trees growing in the $\mathrm{C}$ sampling site. The pines growing in this sampling site were characterized by the highest level of tree ring width reduction in the period of time between 1958-1991.

The absolutely dated annual tree-rings were manually separated as thin slivers and pooled and homogenized. The $\alpha$-cellulose samples were extracted by applying the procedures based on the Green's method (1963) used in The Mass Spectrometry Laboratory of the Silesian University of Technology (Pazdur et al., 2007, 2013; Sensuła et al., 2011a, 2011b; Sensuła and Pazdur, 2013a, 2013b). This method includes the following steps: the removal of lignin, the processing of the holocellulose to $\alpha$-cellulose, bleaching, neutralizing and drying (Green, 1963).

The initial stage of the process involved cutting of annual rings from the cores in the sample producing fine shavings $<0.5 \mathrm{~mm}$ thick, cut from wood with a knife. Afterwards, the samples were treated with a toluene-ethyl alcohol mixture (in proportion $1: 1$, at $80^{\circ} \mathrm{C}$, over 4 hours), ethyl alcohol (at $80^{\circ} \mathrm{C}$, over 4 hours), distilled water (at $80^{\circ} \mathrm{C}$, over 1 hour). The reaction was performed in a Soxhlet apparatus. Afterwards, the samples were dried overnight. The dried and weighed samples were placed into the glass test-tubes. The next step was bleaching with $\mathrm{NaClO}_{2}$ and $\mathrm{CH}_{3} \mathrm{COOH}$ solution $(175 \mathrm{ml}$ of distilled water, $2.5 \mathrm{~g}$ of $\mathrm{NaClO}_{2}$ and $1.7 \mathrm{ml}$ of $\mathrm{CH}_{3} \mathrm{COOH}$ was added per $1 \mathrm{~g}$ of each sample) at $70^{\circ} \mathrm{C}$, over 1 hour in order to remove lignin and to extract cellulose. This process was repeated 5 times. In the next step the solution was removed by decanting. The samples were rinsed with boiling distilled water and then with cold distilled water up to neutral $\mathrm{pH}$. Afterwards, the samples were treated with $50 \mathrm{ml}$ of $10 \% \mathrm{NaOH}$ solution (at $70^{\circ} \mathrm{C}$, over 45 minutes). Afterwards the solution was removed and samples were rinsed with cold distilled water. Then the samples were treated with $17 \% \mathrm{NaOH}$ solution (at room temperature for 45 minutes). The solution was then removed from the tubes and samples were rinsed with distilled water. At the end of the extraction process the samples were treated with $10 \mathrm{ml}$ of $1 \% \mathrm{HCl}$ solution and rinsed up to neutral $\mathrm{pH}$. The obtained $\alpha$-cellulose was dried on a hot plate at $60^{\circ} \mathrm{C}$ overnight. To ensure homogeneity the chemical pre-treatment was carried in an ultrasonic bath.

In order to determine the $\delta^{13} \mathrm{C}$ values, the samples $(0.060 \mathrm{mg})$ were loaded into tin capsules and combusted at a temperature of $1100^{\circ} \mathrm{C}, \mathrm{CO}_{2}$ was separated in a gas 
chromatography column of the elemental analyser (EuroVector). In order to determine the $\delta^{18} \mathrm{O}$ values, the samples $(0.095 \mathrm{mg})$ were loaded into silver capsules. To displace moisture-containing air in the cellulose samples, the samples were heated over 24 hours in a vacuum line $\left(60^{\circ} \mathrm{C}\right)$ and after that they were put into a special air-filled dry box before stable isotope ratio determination (Sensuła et al., 2011b). The samples were converted to $\mathrm{CO}$ by pyrolysis at a temperature of $1350^{\circ} \mathrm{C}$ and separated in a gas chromatography column in the elemental analyser (EuroVector).

The stable oxygen and carbon isotope compositions of the samples were determined using an Isoprime continuous flow isotope ratio mass spectrometer (GV Instruments, Manchester, UK) at the Mass Spectrometry Laboratory of the Silesian University of Technology.

The relative deviation of the isotopic composition is expressed, in parts per thousand (\%o), as $\delta=\left(\mathrm{R}_{\text {sample }} / \mathrm{R}_{\text {standard }}-1\right) \cdot 1000$, where $\mathrm{R}_{\text {sample }}$ and $\mathrm{R}_{\text {standard }}$ are the ratios of the heavy to the light isotope concentration in the sample and in the standard, respectively. The $\delta^{13} \mathrm{C}$ results are reported in values relative to VPDB (Vienna Pee Dee Belemnite), whereas the $\delta^{18} \mathrm{O}$ results are reported in values relative to VSMOW (Vienna Standard Mean Ocean Water). In these measurements, wood (C-5) and $\alpha$-cellulose (C-3) reference materials from IAEA were used.

The isotopic discrimination in photosynthesis was calculated according to the model of Farquhar and Lloyd (1993):

$\Delta^{13} C=\frac{\delta^{13} C_{a i r}-\delta^{13} C_{\text {plant }}}{1+\frac{\delta^{13} C_{\text {plant }}}{1000}}$

$\Delta{ }^{13} \mathrm{C}=\mathrm{a}+(\mathrm{b}-\mathrm{a}) \mathrm{Ci} / \mathrm{Ca}$

where $\mathrm{C}_{\mathrm{i}}$ is intercellular $\mathrm{CO}_{2}$ concentration, $\mathrm{C}_{\mathrm{a}}$ is ambient $\mathrm{CO}_{2}$ concentration, $a(c a .4 .4 \%)$ is the discrimination against ${ }^{13} \mathrm{CO}_{2}$ during $\mathrm{CO}_{2}$ diffusion through stomata, $b$ (ca. 27\%) is the discrimination associated with carboxylation.

\section{RESULTS}

Each of the pine chronologies constructed in this study is a local growth pattern of the pine population. These isotopic records are the result of the response of the trees to variations of various environmental factors: climatic drivers and human activities. For the statistical calculation, Statistica 12 software (StatSoft, Inc., 2014) was applied.

\section{Tree-ring chronologies and dendrochronological indices}

The average width of the radial increment of the studied pine populations ranged from $1.31 \mathrm{~mm}$ to $2.20 \mathrm{~mm}$ (Table 1). Tree-ring width chronologies, apart from their short-term variance are characterised by a clear long-term variance (Fig. 4). Chronologies of sensitivity display a strongly reduced long-term variance while the short-term variance is highlighted. The average sensitivity of pines for the period of 1950-2012 was included in a narrow range from 0.214 to 0.281 , while the $r_{b t}$ index was between 0.399 and 0.521 (Table 1). On the other hand, in all cases the EPS considerably exceeded the minimum value of 0.85 . These results indicate a relatively high sensitivity of the pines, the strength of the climatic signal and representativeness of site chronology. The similarity of year-to-year changes of the tree-ring width of 6 pine populations was relatively high. Tree-ring width chronologies also had a similar long-term course.

In the 1970s the pines strongly reduced their radial increments (Fig. 4). This was a result of the increase in industrial pollution at this time (Fig. 1). The reduction in tree rings radial growth in 2003 and 2006 were due to drought events

It is interesting that the year-to-year sensitivity of trees remained at a similar level throughout the analysed period (Fig. 4). The changes of tree-ring widths from year to year are the result of the impact of the climate on trees. Therefore, it can be assumed that the climate signal contained in the chronologies of pine populations was at a similar level in the analysed period.

Short-term changes of radial increments of the pine populations differed. This diversity is indicated by the location of the site sensitivity chronologies in relation to component loadings of PC1 and PC2 (Fig. 5). Sensitivity chronologies are strongly differentiated mainly by PC2. The A chronology positively correlates with PC2, while the correlation is negative in the case of $\mathrm{S}$ (Fig. 5). Other chronologies (B, C, N and T) show very poor correlation with PC2. They form a compact group and correlate

Table 1. Statistical characteristics of the site chronologies for the 1951-2012 period. TRW - mean tree-ring width; TRI - mean tree-ring index; MS - mean sensitivity; $r_{b t}$ - the mean correlation of standardized series of trees - the signal strength of the chronology, EPS - the expressed population signal is a statistic for examining the common variability in a chronology.

\begin{tabular}{cccccccc}
\hline Site Lat. N, Lon. E & $\begin{array}{c}\text { Elevation } \\
(\mathbf{m})\end{array}$ & $\begin{array}{c}\text { TRW } \\
(\mathbf{c m})\end{array}$ & TRI & MS & $\mathbf{r}_{\mathrm{bt}}$ & EPS \\
\hline $\mathrm{A}$ & $50^{\circ} 19^{\prime}, 18^{\circ} 15^{\prime}$ & 192 & 2.20 & 1.0 & 0.23 & 0.42 & 0.93 \\
$\mathrm{~B}$ & $50^{\circ} 20^{\prime}, 18^{\circ} 18^{\prime}$ & 209 & 1.81 & 1.0 & 0.26 & 0.52 & 0.95 \\
$\mathrm{C}$ & $50^{\circ} 20^{\prime}, 18^{\circ} 19^{\prime}$ & 218 & 1.31 & 1.0 & 0.28 & 0.49 & 0.95 \\
$\mathrm{~N}$ & $50^{\circ} 22^{\prime}, 18^{\circ} 23^{\prime}$ & 218 & 1.80 & 1.0 & 0.21 & 0.39 & 0.93 \\
$\mathrm{~S}$ & $50^{\circ} 18^{\prime}, 18^{\circ} 20^{\prime}$ & 215 & 1.48 & 1.0 & 0.22 & 0.46 & 0.93 \\
$\mathrm{~T}$ & $50^{\circ} 18^{\prime}, 18^{\circ} 17^{\prime}$ & 207 & 1.77 & 1.0 & 0.26 & 0.49 & 0.95 \\
\hline
\end{tabular}



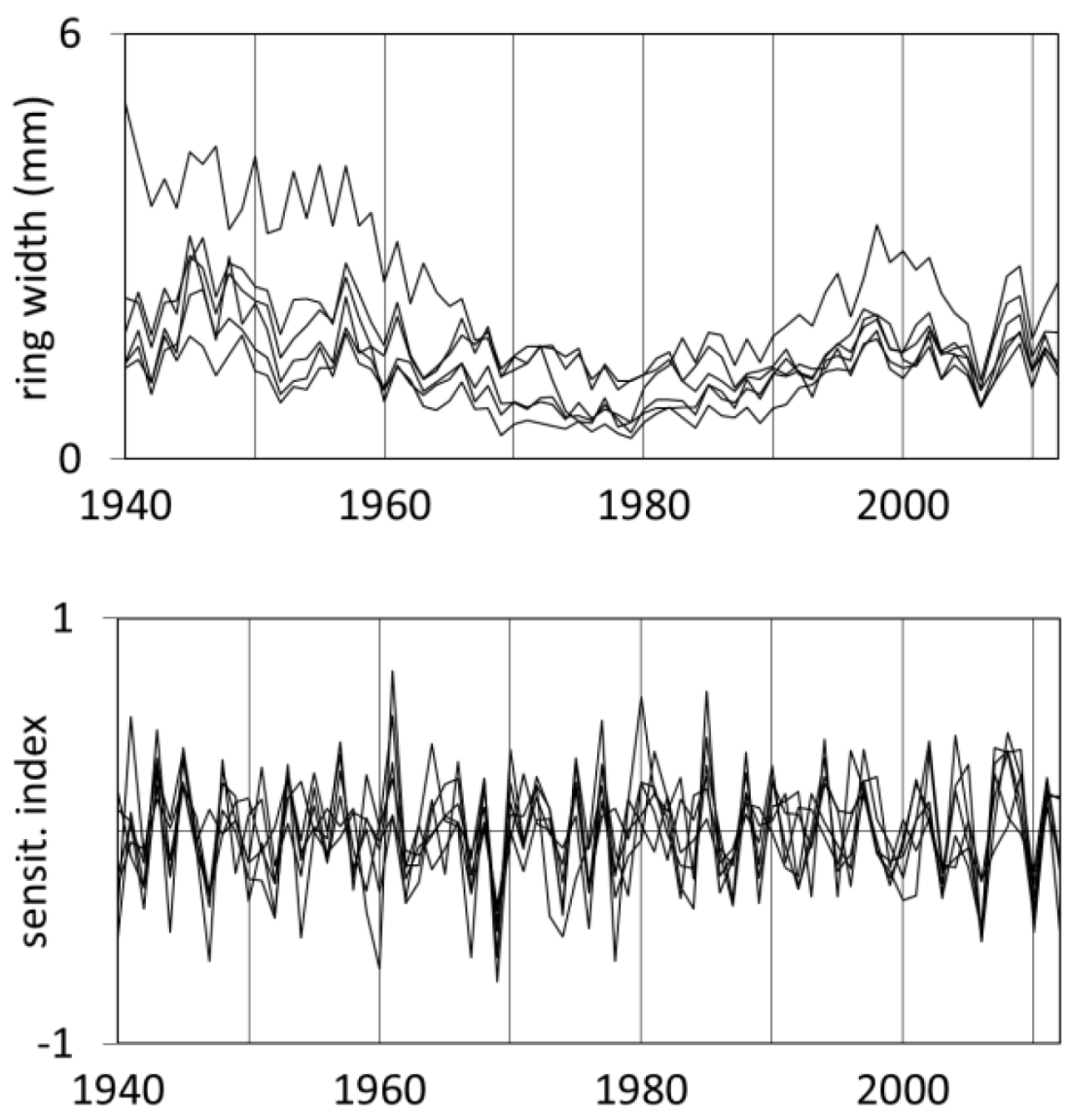

Fig. 4. The course of 6 sites tree-ring width chronologies (top) and sites sensitivity chronologies (bottom).

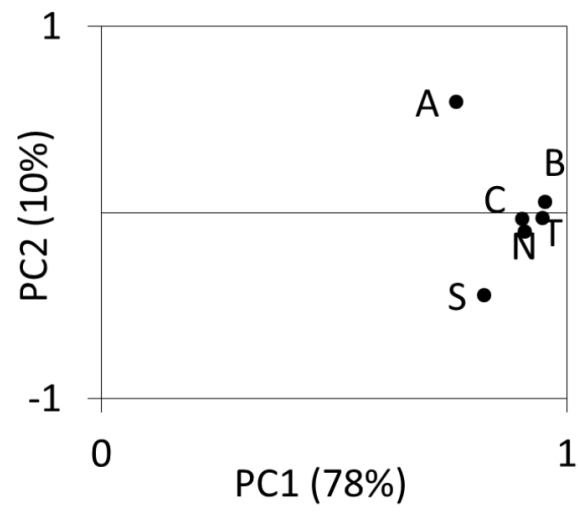

Fig. 5. Comparison of the loadings of the first and second principal components for 6 sites (A,B, C, N, S, T, see Table 1) sensitivity chronologies. strongly with $\mathrm{PC} 1$, while the chronology of populations $\mathrm{A}$ and $\mathrm{S}$ correlate poorly with PC1 (Fig. 5). The PC1 accounts for $78 \%$ of the variance among 6 sensitivity chronologies and the PC2 accounts for 10\%. PC1 was most effective for explaining the variance of the radial growth of the pines.

Climate determines the short-term variance of incremental reaction of trees. This kind of variance is illustrated by sensitivity chronologies. It can therefore be assumed that the two main components - PC1 and PC2 depict the climate factors that had a significant impact on the variance of radial increments of pines. This is confirmed by the results of cluster analysis. It was found that a series of correlation coefficients for the populations B, $\mathrm{C}, \mathrm{N}$ and $\mathrm{T}$ formed a single cluster, while the series of populations A and S differed significantly (Fig. 6). 
With the response function analysis, the climate features described by PC1 and PC2 were identified (Fig. 7). It turned out that PC1 correlated significantly $(p<0.05)$ with monthly values of relative humidity and precipitation of September of the preceding year, humidity, temperature and sunshine duration of spring months and with rainfall, temperature, and sunshine duration of the summer months in the year of ring formation (Fig. 7). On the other hand, PC2 correlated significantly $(p<0.05)$ with the humidity, sunshine duration, temperature and rainfall of spring and summer months of the current year, and in addition with the rainfall in January and temperatures of September and December of the previous year (Fig. 7).

In 3 cases PC1 and PC2 were significantly correlated with the same climate parameters. This applies to relative humidity, rainfall and sunshine duration in May of the year of ring formation (Fig. 7). The impact of climatic conditions of this month on the radial increment of pines therefore requires thorough consideration. The principal component analysis showed that the climatic factors described by PC1 have a similar effect on the radial increment of 6 pine populations. In turn, climate elements described by PC2 were differentiated by the incremental rhythm in pine growth (see Fig. 5). The above results were verified by correlating these climate parameters with site sensitivity chronologies (Fig. 8). It turned out that the relation between a relative radial increment and the temperature of February, March and August were very similar in all populations (Fig. 8). These results correspond with the results obtained for PC1 (Fig. 8).
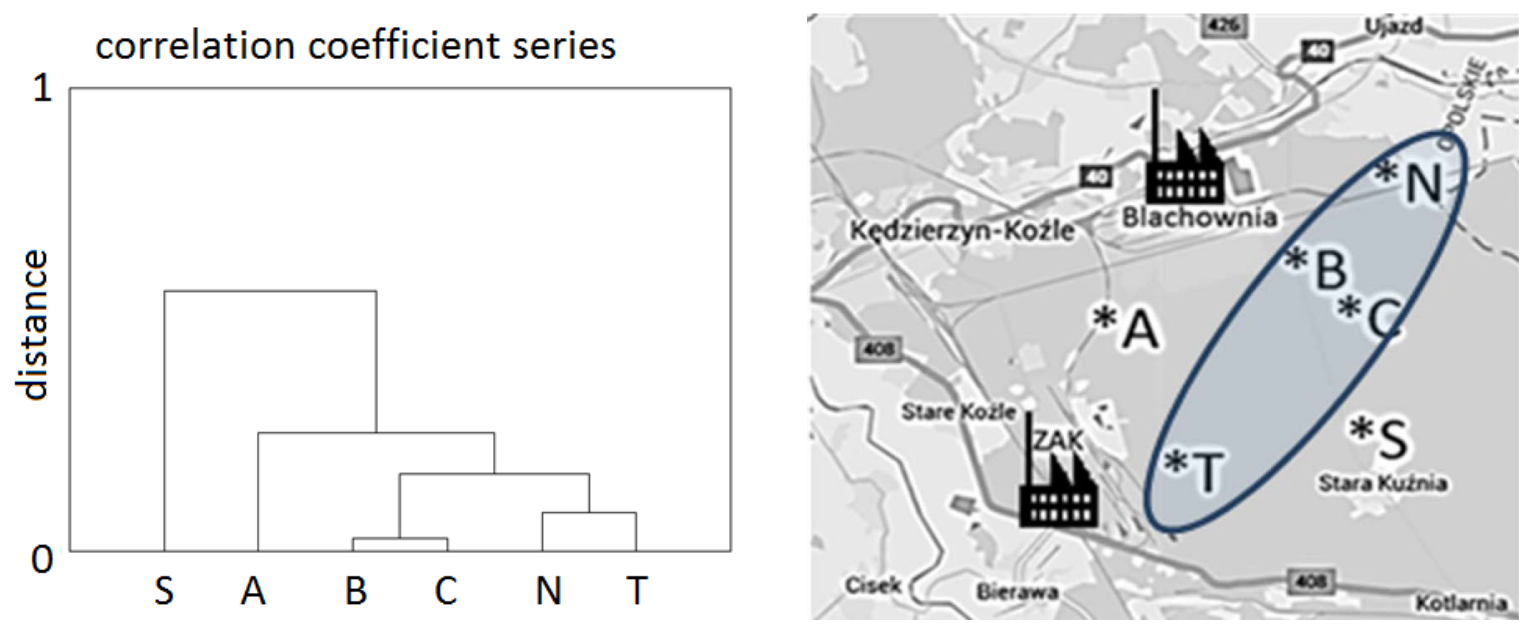

Fig. 6. The dendrogram of clusters of pine population ( $A, B, C, N, S, T$, see Table 1) based on the similarity of their response to climatic conditions. Localization of the pine population with similar response.

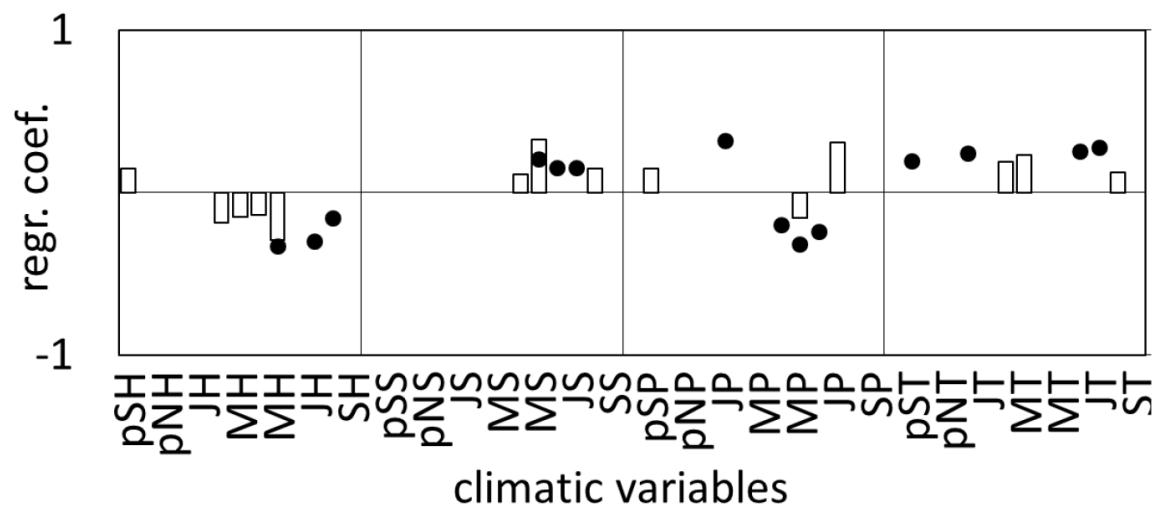

Fig. 7. Significant (at $p<0.05)$ regression (response function) coefficients calculated between PC1 (white bars), and PC2 (black dots) and monthly temperature $(T)$, precipitation $(P)$, sunshine duration $(S)$ and relative humidity $(H)$ from September of the previous year $(p S)$ to September of the given year (S). 

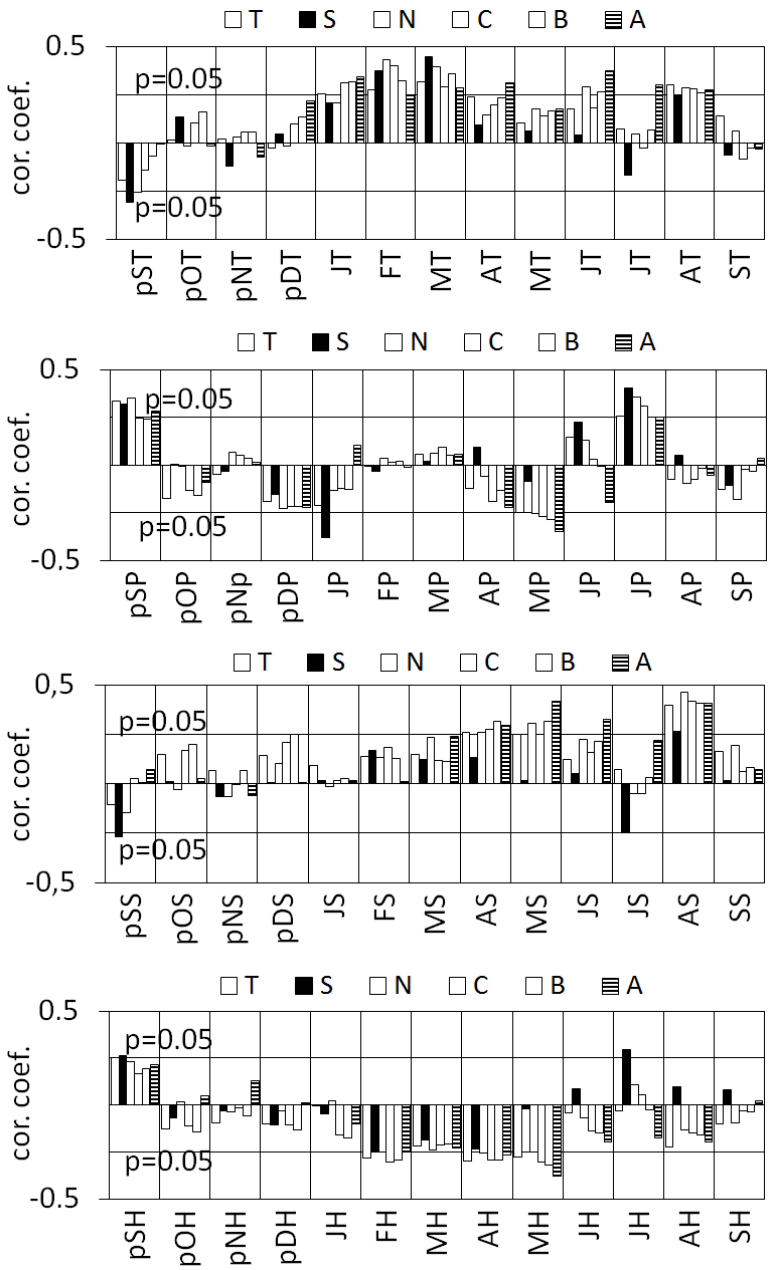

Fig. 8. Correlation coefficients between site $(A, B, C, N, S, T$, see Table 1) sensitivity chronologies and monthly climatic variables: temperature $(T)$, precipitation $(P)$, sunshine duration $(S)$ and relative humidity $(H)$ from September of the previous year (pS) to September of the given year (S).

The results were similar in the case of rainfall of the previous September and of current May and July. The similar sensitivity of 6 pine populations to the amount of sunshine duration in April, May and August was also discovered. Similar patterns are connected with the effect of relative humidity of the previous September, and current February, March and April (Figs. 7 and 8).

The results of response function analysis performed for PC2 were also confirmed. It turned out that the incremental sensitivity of pine populations $A$ and $S$ to the temperature of the previous September and December and current June and July was different. It also differed from the sensitivity of the remaining pine populations (B, C, N and T) (Fig. 8). A difference was also observed regarding the effect of precipitation of January, April, May and June of the current year on increments of the A and S populations (Fig. 8). Differences were also found in the responses of pine trees on site $\mathrm{A}$ and $\mathrm{S}$ to the sunshine of the previous September and in the period between May and July of the year of ring formation. Also, the humidity of May, July and August had a different effect on the radial increment of pine trees on both of the above positions (Fig. 8). These climatic parameters were described by the other main component which differentiated the incremental rhythm of population A and C (Fig. 7).

The impact of rainfall, sunshine duration and relative humidity in the May of the ring formation year on pine radial increments was specific. On the one hand, the conditions above have had a similar effect on the incremental reactions of pines in all populations, as monthly values of these elements significantly correlate with PC1. On the other hand, they differentiate the incremental rhythm of each population, as they significantly correlate with PC2 (see Figs. 7 and 8). This paradox is explained by the results of the site chronology correlation analysis with the climatic parameters of May. It turned out that the direction of these relations is similar in 6 populations. However, increments of the $\mathrm{S}$ population of pines do not show a significant relationship with the above parameters of May, and population A has the strongest relation with the above (Fig. 8). It shows the similarity of the relation, but also highly diversified strength of these relations.

\section{$\delta^{18} \mathrm{O}$ and $\delta^{13} \mathrm{C}$ chronologies}

Analysis of stable isotope fractionation in annual tree rings of pines, growing in the sampling site where the strongest reduction of tree ring width was noted, is the complemental analysis to dendrochronological method. The pine tree-ring isotopic chronologies constructed in this study is a local grown pattern of the partial pine population (site C). These isotopic records (Fig. 8) are the result of the response of the trees to variations of various environmental factors such as climatic factors and human activities.

$\delta^{18} \mathrm{O}$ values varied between $27.4 \%$ to $31.8 \%$ o (Fig. 9), whereas $\delta^{13} \mathrm{C}$ ranged from $-24.6 \%$ to $-22.9 \%$. The $\delta^{13} \mathrm{C}$ changes in the isotopic ratio of atmospheric $\mathrm{CO}_{2}$ due to global fossil fuels emissions ranged from $0.37 \%$ (in 1975 ) to $1.97 \%$ o (in 2012). This correction lifts the $\delta^{13} \mathrm{C}$ values (Fig. 9). The $\delta^{13} \mathrm{C}$ values corrected for changes in the isotopic ratio of atmospheric $\mathrm{CO}_{2}$ ranged from $-23.6 \%$ to $-21.5 \%$.

The analysis of combined measurement of carbon and oxygen isotopes ratio (Fig. 10) show positive significant correlation between $\delta^{13} \mathrm{Cand} \delta^{18} \mathrm{O}$ in the period of time from 1991-2012. No significant $\delta^{18} \mathrm{O}-\delta^{13} \mathrm{C}$ relationship was observed between 1975 and 1990 .

To describe the variation of the carbon and oxygen isotope composition of cellulose in annual tree-rings of pine caused by climate changes and human activities we used a model (Sensuła and Pazdur, 2013a, 2013b) based on multiple regressions (Fig. 11, Table 2): 


$$
\begin{aligned}
& \delta=b_{a}+\sum_{M=A p r}^{\text {Sept }} b_{M T} T_{M}+\sum_{M=A p r}^{\text {Sept }} b_{M P} P_{M}+ \\
& \sum_{M=A p r}^{\text {Sept }} b_{M S} S_{M}+\sum_{M=A p r}^{\text {Sept }} b_{M H} H_{M}
\end{aligned}
$$

where $\mathrm{M}$ is the month (from April to September), $\mathrm{b}$ is the regression coefficient for the following variables: $T$ (mean of the monthly maximum temperatures), P (monthly precipitation sum), $\mathrm{S}$ (monthly hours of sunshine duration), $\mathrm{H}$ (mean of the monthly relative humidity), whereas $b_{a}$ corresponds to the interdependences between the monthly climate factors and other environmental changes.

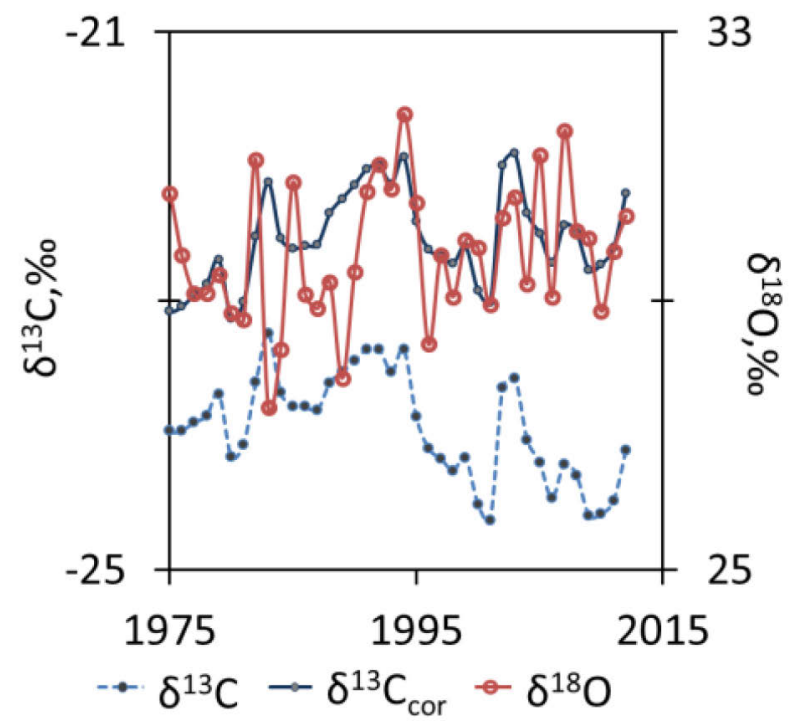

Fig. 9. Stable carbon and oxygen isotopes chronologies. The raw $\delta^{13} \mathrm{C}$ values (dashed line) have been corrected ( $\delta^{13} C_{\text {cor }}$ values solid line) for changes in the isotopic ratio of atmospheric $\mathrm{CO}_{2}$.

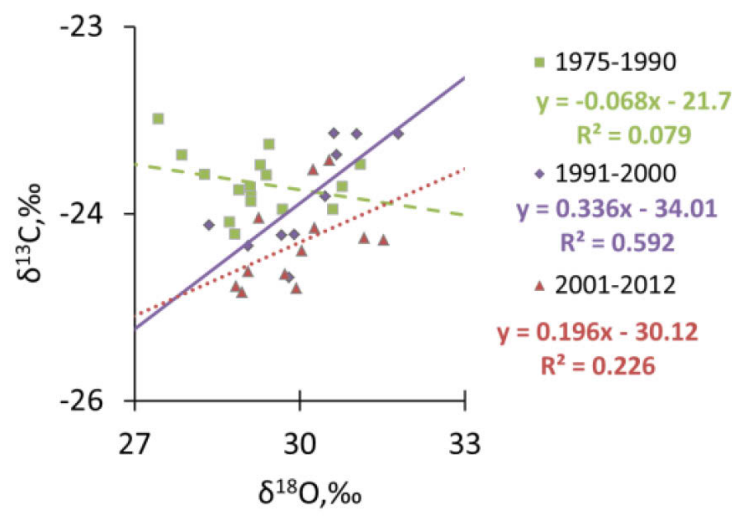

Fig. 10. Correlation between $\delta^{13} \mathrm{C}$ and $\delta^{18} \mathrm{O}$ chronologies of Scots pine growing in the industrial area.
The value of the correlation coefficient between the measured and modelled $\delta^{13} \mathrm{C}$ in $\alpha$-cellulose is equal to 0.93 , whereas the value of the correlation coefficient between the measured and modelled $\delta^{18} \mathrm{O}$ in $\alpha$-cellulose is equal to 0.78 .

\section{Water use efficiency (WUE) and temperature anomaly}

Diffuse air pollution (carbon dioxide) caused the variation in the ratio of water used in plant metabolism to water lost by the plant through transpiration (WUE). In the period of time from 1975 and 2012, according to NASA (2016) the global concentration of midtropospheric carbon dioxide ranged from $c a .330 \mathrm{ppm}$ to ca. $393 \mathrm{ppm}$ whereas the global surface temperature, relative to 1951-1980 average temperatures, ranged from $-0.01^{\circ} \mathrm{C}$ to $0.76^{\circ} \mathrm{C}$. During this period, the water use efficiency values increases from 94 to $122 \mu \mathrm{mol} / \mathrm{mol}$ (Fig. 12). It has been observed that with increase of $\mathrm{CO}_{2}$ emission also WUE increases. Water use efficiency might be strongly correlated with variability of the surface temperature $(\mathrm{r}=0.81)$
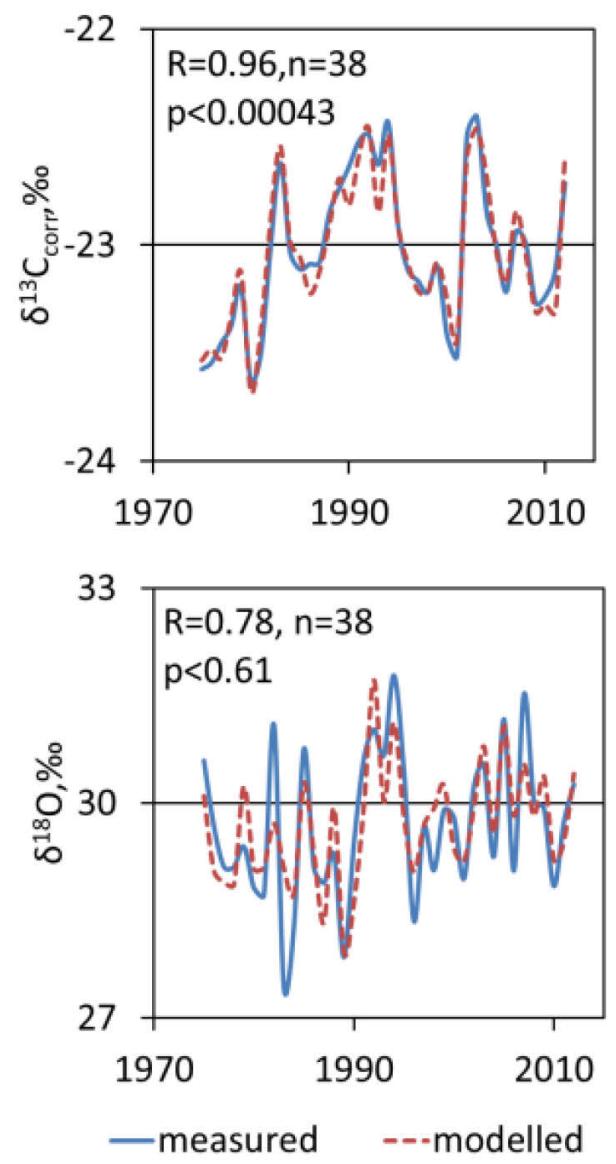

Fig. 11. Measured (solid lines) and modelled (dashed line) values of carbon and oxygen stable isotopic composition of $\alpha$-cellulose samples extracted from annual tree rings of pine (1975-2012). 
Table 2. The regression coefficient (Eq. 3.1) for the following variables: $T$ (mean of the monthly maximum temperatures), $P$ (monthly total precipitation), $S$ (monthly hours of sunshine duration), $H$ (mean of the monthly relative humidity). $b_{i}-$ multiple regression parameters. The test of significance gives a $p$-value $(n=38)$.

\begin{tabular}{|c|c|c|c|c|c|}
\hline \multirow{2}{*}{ Variables } & \multirow{2}{*}{ Units } & \multicolumn{2}{|c|}{$\delta^{13} C_{\text {cor }}$} & \multicolumn{2}{|c|}{$\delta^{18} 0$} \\
\hline & & $b_{i}$ & $p_{i}$ & $b_{i}$ & $p_{i}$ \\
\hline$\overline{b_{a}}$ & $\%$ & -15.85 & 0.004 & -34.53 & 0.267 \\
\hline $\mathrm{T}_{\text {Apr }}$ & $\% /{ }^{\circ} \mathrm{C}$ & -0.028 & 0.133 & -0.103 & 0.391 \\
\hline$T_{\text {May }}$ & $\% /{ }^{\circ} \mathrm{C}$ & -0.043 & 0.156 & 0.421 & 0.043 \\
\hline$T_{\text {Jun }}$ & $\% /{ }^{\circ} \mathrm{C}$ & 0.037 & 0.106 & 0.026 & 0.857 \\
\hline TJul & $\% /{ }^{\circ} \mathrm{C}$ & -0.007 & 0.817 & 0.306 & 0.129 \\
\hline$T_{\text {Aug }}$ & $\% /{ }^{\circ} \mathrm{C}$ & 0.047 & 0.110 & 0.219 & 0.247 \\
\hline$T_{\text {Sep }}$ & $\% /{ }^{\circ} \mathrm{C}$ & -0.019 & 0.352 & -0.001 & 0.993 \\
\hline$P_{\text {Apr }}$ & $\% 0 / \mathrm{mm}$ & 0.001 & 0.556 & 0.004 & 0.755 \\
\hline$P_{\text {May }}$ & $\% 0 / \mathrm{mm}$ & -0.003 & 0.079 & 0.004 & 0.693 \\
\hline$P_{\text {Jun }}$ & $\% 0 / \mathrm{mm}$ & -0.001 & 0.596 & -0.007 & 0.588 \\
\hline$\overline{P_{\text {Jul }}}$ & $\% \mathrm{~mm}$ & -0.001 & 0.592 & -0.009 & 0.270 \\
\hline$P_{\text {Aug }}$ & $\% 0 / \mathrm{mm}$ & 0.002 & 0.148 & -0.002 & 0.797 \\
\hline$P_{\text {Sep }}$ & $\% 0 / \mathrm{mm}$ & -0.001 & 0.652 & 0.002 & 0.872 \\
\hline $\mathrm{S}_{\text {Apr }}$ & $\% /$ hours of sunshine & -0.003 & 0.179 & 0.020 & 0.124 \\
\hline$S_{\text {May }}$ & $\%$ / hours of sunshine & 0.001 & 0.521 & -0.021 & 0.110 \\
\hline $\mathrm{S}_{\text {Jun }}$ & $\%$ / hours of sunshine & 0.007 & 0.003 & -0.008 & 0.541 \\
\hline S Jul & $\%$ / hours of sunshine & -0.006 & 0.045 & 0.029 & 0.107 \\
\hline $\mathrm{S}_{\text {Aug }}$ & $\% 0 /$ hours of sunshine & 0.003 & 0.125 & -0.007 & 0.497 \\
\hline Ssep & $\%$ / hours of sunshine & -0.006 & 0.013 & 0.019 & 0.205 \\
\hline $\mathrm{H}_{\mathrm{Apr}}$ & $\% 0 / \%$ & -0.044 & 0.104 & 0.290 & 0.106 \\
\hline $\mathrm{H}_{\text {May }}$ & $\% 0 / \%$ & 0.040 & 0.090 & -0.237 & 0.128 \\
\hline $\mathrm{H}_{\text {Jun }}$ & $\% 0 / \%$ & 0.088 & 0.009 & -0.150 & 0.446 \\
\hline $\mathrm{H}_{\mathrm{Jul}}$ & $\% 0 / \%$ & -0.064 & 0.104 & 0.474 & 0.071 \\
\hline $\mathrm{H}_{\text {Aug }}$ & $\% 0 / \%$ & -0.009 & 0.672 & -0.038 & 0.782 \\
\hline $\mathrm{H}_{\mathrm{sep}}$ & $\% 0 / \%$ & -0.090 & 0.001 & 0.120 & 0.374 \\
\hline
\end{tabular}
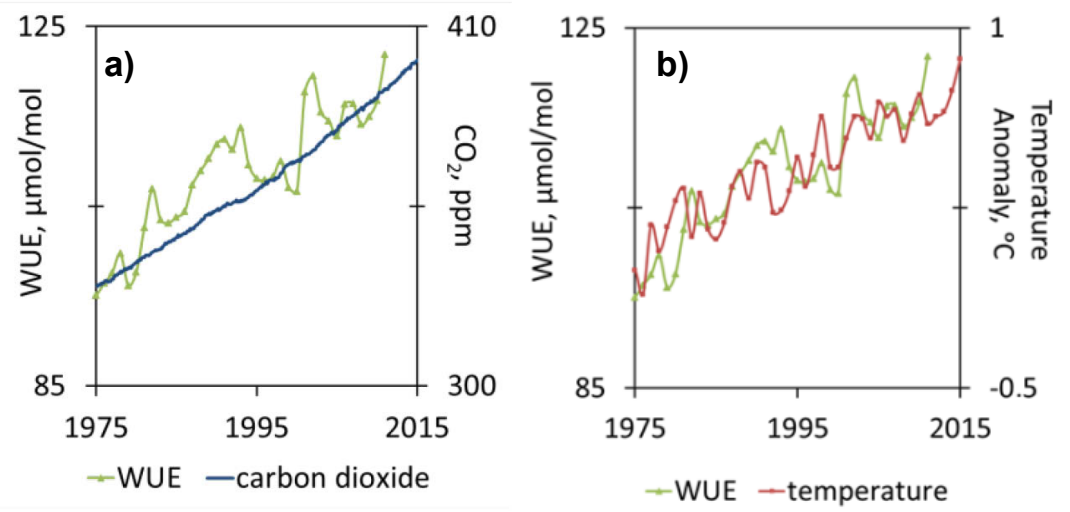

c)

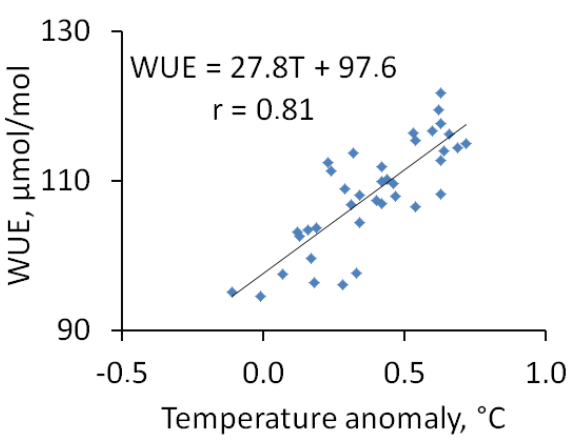

Fig. 12. (a) Changes in water use efficiency (WUE) due to global distribution and variation of the concentration of mid-tropospheric carbon dioxide in parts per million (ppm) and (b) global surface temperature relative to 1951-1980 average temperature (c) correlation between water use efficiency and the variability of the global surface temperature.

\section{DISCUSSION}

\section{Tree-ring chronologies}

Site chronologies of radial increment sizes represent incremental patterns of pines from partial populations. They illustrate the specific response of pine trees to various environmental factors, including the climate factor. It should be emphasized that in the years 1951-2012 the size of radial increments of the studied pine population changed. In the 1970s pines strongly reduced their radial increment. The reason for the reduction was a strong increase in industrial pollution. Despite this fact, pines in the area preserved their high year-to-year sensitivity to short-term impulses from the environment. It turned out, 
however, that the year-to-year rhythm of radial increments in particular populations was different. The reason was their different sensitivity to particular elements of the climate. In particular, two pine populations (S and $\mathrm{A}$ ) were different in this respect - both, from each other and from the other four populations. They are located away from the main flow of air masses carrying pollutants from local factories. It is therefore assumed that the differences in the relations between climate and radial increments were the result of the varying pressure of pollution on the studied populations of trees. However, the influence of other factors, such as unrecognized differences in habitat conditions and the age of the trees cannot be excluded. Site A pines were in fact younger than others by approx. 20 years.

The differences in sensitivity of pines from $\mathrm{A}$ and $\mathrm{S}$ populations to the climatic elements described by PC2 were confirmed by the analysis of site chronology correlations. The Principal component analysis (PCA) is therefore an effective method of recognizing the similarities and differences in the sensitivity of trees to the climatic factor.

Interpretation of the modifying effect of pollutants on the relation between climate and tree increments is difficult. The influence of pollutants depends on the distance of trees from the emitters, the position of sites in relation to the direction of wind carrying pollutants, the age of trees and habitat conditions in which trees grow (Carrer and Urbinati, 2004; Yu et al., 2008; Friedrichs et al., 2009; Dauskane et al., 2011; Wilczyński, 2013; Sensuła et al., 2015a, 2015b).

A significant influence of the climatic conditions of the current and previous year on pine radial increments was observed. This is confirmed by numerous dendroclimatic studies on Scots pine (Vaganov, 1990; Lührte, 1991; Richter et al., 1991; Lindholm et al., 1996; Wilczyński and Skrzyszewski, 2003; Wilczyński, 2003, 2013; Pensa et al., 2005; Tuovinen, 2005; Juknys et al., 2014; Helama et al., 2013).

A strong positive correlation of site chronologies with the first main component indicates that pines showed similar sensitivity to climatic influences of PC1. Their role in shaping thickness increment of pines was independent of other elements of the environment. The results indicate that a cool, humid and rainy September meant that all the pine populations increased their increments in the following year. High temperatures and low air humidity in the autumn has a positive effect on the flowering of female flowers in the following year (Andersson, 1965; Fober, 1976). This has a negative impact on incremental growth of trees (Eis et al., 1965; Chałupka et al., 1976). On the other hand, cloudy, humid weather with plenty of rainfall has a beneficial effect on the number of buds of vegetative organs - needles and shoots (Hejnowicz, 1982). Therefore, the surface of assimilation and production of auxins increases, which speeds cambial divisions and growth of trees. It was also found that hot, short and sunny winters and dry air in this season positively influence the condition and incremental ability of 6 populations of Scots pine. Such conditions gave an earlier start to physiological processes that led to earlier and faster divisions of the cambium (Schober, 1951; Ermich, 1959; Wodzicki and Zajączkowski, 1983). A similar positive role was played by a dry, sunny and warm spring. These relations are confirmed in other dendroclimatic studies of the pine (Richter et al., 1991; Wilczyński and Skrzyszewski, 2003; Wilczyński, 2003; Juknys et al., 2014). The positive impact on the creation of the pine wood cells was also exerted by high rainfall in July of the year when the ring was formed, as they caused the extension of the period of intensive divisions of vascular cambium and the formation of large diameter cells. Low rainfall in summer is often a factor limiting the incremental growth of Scots pine basically throughout all of its range (Lührte, 1991; Lindholm et al., 1997; Irvine et al., 1998; Cinnirella et al., 2002; Wilczyński and Skrzyszewski, 2003; Pensa et al., 2005; Tuovinen, 2005; Pilcher and Oberhuber, 2007; Piovesan et al., 2008; Gruber et al., 2010; Juknys et al., 2014). Drought is a factor which often induces variability in growth patterns and mortality of Scots pine especially in dry areas (Bigler et al., 2006, Hereş et al., 2012, Herguido et al., 2016, Marqués et al., 2016). Heavy rainfall during the growing season and, consequently, increased air humidity enhances the flow of water into the cells increasing the pressure on the cell wall, thus stretching these and causing cambium cell growth and it also provides the substrates for the process of photosynthesis (Major and Johnsen, 2001). In turn, the deficit of water within this period reduces the turgor of the cell, decreasing the dividing activity of the vascular cambium (Pichler and Oberhuber, 2007). It also happens that excess of water harms trees, but mostly those on very humid sites (Cedro and Lamentowicz, 2011; Helama et al., 2013; Wilczyński, 2013).

\section{$\delta^{18} \mathrm{O}$ and $\delta^{13} \mathrm{C}$ chronologies}

The determination of properties of tree-rings is crucial for many applications in the investigation of local and global environmental changes. Since the beginning of the $20^{\text {th }}$ century, there has been much discussion about how external environmental factors, including climate changes and anthropogenic effects affect the physiological processes that control tree growth (Schweingruber, 1996; DeVries et al., 2000; McCarroll and Loader, 2004; Pazdur et al., 2007, 2013; Sensuła et al., 2015a, 2015b; Sensuła, 2015). Through photosynthesis, plants convert $\mathrm{CO}_{2}$ and $\mathrm{H}_{2} \mathrm{O}$ to saccharides $\left(\mathrm{C}_{6} \mathrm{H}_{12} \mathrm{O}_{6}\right)$, using light, and release oxygen to the atmosphere. The carbon of annual tree-ring has its origin in the $\mathrm{CO}_{2}$ of air, whereas the oxygen has its origin in the soil water and thus precipitation. The primary value of the isotopic records in treerings is not simply as samples of ancient air or water, but as sensitive bio-indicators of the way that the components of air and water have been changed by the trees in re- 
sponse to the environments in which they grown (Craig, 1954; Ehrelinger and Vogel, 1993; McCarroll and Loader, 2004; Savard, 2010; Sensuła, 2015).

The carbon isotopic composition $\left(\delta^{13} \mathrm{C}\right)$ of trees has been influenced by carbon isotopic composition of atmospheric $\mathrm{CO}_{2}$, diffusion of $\mathrm{CO}_{2}$ through stomata, and enzymatic discrimination during the irreversible step of $\mathrm{CO}_{2}$ fixation (Roden et al., 2000). The isotopic composition of plants varied due to emission of atmospheric pollution (Savard, 2010), such as for example sulphur dioxide (Rinne et al., 2010), carbon dioxide (Craig, 1954; McCarroll and Loader, 2004; Pazdur et al., 2007, 2013; Sensuła et al., 2011a, 2011b; Sensuła and Pazdur, 2013a, 2013b; Sensuła, 2015).

Trees grown at the higher level of $\mathrm{CO}_{2}$ concentration had a more negative $\delta^{13} \mathrm{C}$ than trees grown at the lower concentration. In pine, $\mathrm{CO}_{2}$ usually limits photosynthesis and, thus, an increase in $\mathrm{CO}_{2}$ results in greater photosynthetic rates. Raw $\delta^{13} \mathrm{C}$ data can be corrected to a preindustrial atmospheric $\delta^{13} \mathrm{C}_{\text {cor }}$ base value of $6.4 \%$ using the data from McCarroll and Loader (2004), due to decreasing $\delta^{13} \mathrm{C}$ in the air and the biosphere is associated with the increasing of anthropogenic $\mathrm{CO}_{2}$ in the atmosphere (Craig, 1954; Farquhar and Lloyd, 1993; Field et al., 1995; McCarroll and Loader, 2004; Pazdur et al., 2007, 2013; Keeling et al., 2010; Sensuła and Pazdur 2013a, 2013b; Battipaglia et al., 2014; Saurer et al., 2014). The analysis of the influence of pollution on stable isotopes composition will be a theme of the future study. Carbon dioxide $\left(\mathrm{CO}_{2}\right)$ is an important heat-trapping (greenhouse) gas, which is released through human activities such as deforestation and burning fossil fuels, as well as natural processes such as respiration and volcanic eruptions. According to NASA (2016), and IPCC (2005), the extent of climate change effects on individual regions will vary over time and with the ability of different societal and environmental systems to mitigate or adapt to change. The IPCC predicts that increases in global mean temperature of less than 1 to 3 degrees Celsius above 1990 levels will produce beneficial impacts in some regions and harmful ones in others. Net annual costs will increase over time as global temperatures increase.

Researchers have used correlation analyses to determine which environmental parameters (precipitation, sunshine, humidity, and temperature) might be recorded in the isotopic composition of cellulose extracted from the annual growth rings (Schiegl, 1974; Gray and Thompson, 1976; Epstein and Yapp, 1977; Burk and Stuiver, 1981).

According to the scientific literature, the carbon isotopic composition in plant can vary with water stress and solar radiation and can be correlated with amount of rainfall, vapour pressure deficit, canopy position and hydraulic conductivity associated with tree height (Dongmann et al., 1974; Ehleringer, 1990; Ehrelinger and Vogel, 1993; Comstock and Ehleringer, 1992; Buchmann et al., 2002; Yoder et al., 1994; Barbour et al., 2002), whereas the oxygen isotopic composition of trees can be influenced by the oxygen isotopic composition of meteoric water and atmospheric vapour, atmospheric humidity and vapour pressure deficit (Farquhar and Lloyd, 1993; Roden et al., 2000). The oxygen isotopic composition of plant has been correlated with air temperature, relative humidity, transpiration rates and water balance, presumably all through contributions of source water (the xylem water in suberized stems) and leaf water enrichment (Ehrelinger and Vogel, 1993). In our studies, the impact of weather conditions on the isotopic concentration in pine was observed. The most significant climate factors $(p<0.05$, where $p$ is the significance level) influencing $\delta^{13} \mathrm{C}$ is the monthly humidity in September $(\mathrm{p}=0.026)$, whereas the most significant climate factors influencing $\delta^{13} \mathrm{C}_{\text {cor }}$ are the monthly humidity in June $(\mathrm{p}=0.009)$ and September $(p=0.001)$, sunshine in June $(p=0.003)$, July $(p=0.045)$ and September $(p=0.013)$, whereas the most significant climate factors influencing $\delta^{18} \mathrm{O}$ in the investigated area is the mean of the May monthly maximum temperatures $(\mathrm{p}=0.043)$. The climatic signal record in trees stable isotopes chronologies may be masked by air contamination. Previous studies have shown weakened climate signal in $\delta^{13} \mathrm{C}$ and $\delta^{18} \mathrm{O}$ of $\alpha$-cellulose of tree ring cellulose as well as deviant trends between $\delta^{13} \mathrm{C}$ and $\delta^{18} \mathrm{O}$ series caused by pollution during the $20^{\text {th }}$ century (Rinne et al., 2010, Boettger et al., 2014, Sensuła, 2016b).

According to models (Farquhar and Lloyd, 1993; Scheidegger et al., 2000) a positive correlation of the $\delta^{18} \mathrm{O}$ and $\delta^{13} \mathrm{C}$ is predicted when $\Delta^{13} \mathrm{C}$ is driven by a strong stomatal reaction, whereas $\mathrm{A}_{\max }$ (photosynthetic capacity) is relatively unaffected. Saurer et al. (1997) found a positive correlation between $\delta^{18} \mathrm{O}$ and $\delta^{13} \mathrm{C}$ of stem organic matter for pine trees growing in habitats with moist and dry soil conditions. The slopes in the $\delta^{18} \mathrm{O}-\delta^{13} \mathrm{C}$ plots were found to be species-dependent and were interpreted as due to differing sensitivity to the moisture conditions. Generally, a positive correlation between oxygen and carbon isotopes might be expected in situations when water is not limiting, because there is no need to reduce water loss, which allows the stomata to operate over a wide range (Scheidegger et al., 2000).

A negative $\delta^{18} \mathrm{O}-\delta^{13} \mathrm{C}$ relationship could be regarded as an indication that plants have stomata with a limited operational range (Scheidegger et al., 2000). According to Saurer and Siegwolf (2007) the stronger response of photosynthetic capacity (Amax) indicate that some species were able to enhance biomass accumulation due to increasing $\mathrm{CO}_{2}$ during the last decade, whereas other species responded more strongly with reduced stomatal conductance and less transpiration and water loss.

Spatial variability and temporal trends in water-use efficiency of European forests up until 2000AD has been studied in several tree species. Experimental results show that plants are able to increase their water-use efficiency (WUE) as $\mathrm{CO}_{2}$ levels rise (Ehlelinger et al., 1993; Morison, 1993; Field et al., 1995; Gagen et al., 2011; Saurer et 
al., 2014; Sensuła, 2015; 2016a). Increased atmospheric $\mathrm{CO}_{2}$ concentration may stimulate plant growth, indirectly through reduced plant water consumption and hence slower soil moisture depletion, and directly through enhanced photosynthesis (Morgan et al., 2004). According to NASA (2016) the variability in the global surface temperature might be due to increase of global $\mathrm{CO} 2$ emissions. According to NASA (2016) the land surface temperature is described as a measurement of how hot the land is to the touch. It differs from air temperature because land heats and cools more quickly than air. Most recent literature (for example, Stips et al., 2016) confirm that the total greenhouse gases (GHG), are the main drivers of the changing global surface air temperature. It has been observed that the elevated $\mathrm{CO}_{2}$ increases intrinsic water use efficiency (WUE) of forests, but the magnitude of this effect and its interaction with climate is still poorly understood. The analysis of the influence of variability of the global surface temperature due to increase of global $\mathrm{CO}_{2}$ anthropogenic emissions on WUE will be a subject of future analyses.

\section{CONCLUSIONS}

The studied populations of Scots pine showed sensitivity to a wide range of meteorological factors occurring in a climate window covering the previous and current ring-forming year. Although pine is a boreal species, cold and long winters have a negative impact on its incremental activity. This relationship holds over the entire geographical range where pines can be found. Industrial pollution caused a reduction in the incremental growth of pines, but this fact does not have a significant impact on its short-term incremental sensitivity. Thanks to the above, a clear climate-radial increment relation was observed.

However, incremental rhythm of the studied pine populations was not identical. This was due to their different sensitivities to some factors of the climate. It was not possible, however, to unambiguously specify the factor that modified the relationship between climate and incremental growth in trees on particular sites. A different degree of the pollution pressure on trees might possibly be a factor shaping their different sensitivity to particular meteorological factors. These could also be other environmental factors. In order to obtain a reliable model based on the relationship between climate and incremental growth for this species, many different subpopulations should be studied on a given area. The principal component analysis proved to be an effective tool in identifying climate factors having a similar and different impact on the incremental rhythm of the studied pines.

The isotopic records in tree-rings can be a sensitive bio-indicators of the way that the components of air and water have been changed by the trees in response to the environments in which they grown. The carbon isotopic composition of trees has been influenced by carbon iso- topic composition of atmospheric $\mathrm{CO}_{2}$. Also, the impact of weather conditions on the isotopic concentration in pine has been observed. The most significant climate factors influencing $\delta^{13} \mathrm{C}_{\text {cor }}$ are the monthly humidity and sunshine in summer. Whereas the most significant climate factors influencing $\delta^{18} \mathrm{O}$ in the investigated area was the mean of the May monthly maximum temperatures.

Based on measurements of $\delta^{18} \mathrm{O}$ and $\delta^{13} \mathrm{C}$ in two periods of time (1) prior to 1990s (where high pollution also recorded in tree ring width reduction) in and (2) after 1990s' (when the pollution was reduced). Only in the period of time between $1990-2012, \delta^{13}$ Cand $\delta^{18}$ O showed a positive significant correlation that indicated a strong stomatal reaction, whereas Amax was relatively unaffected. It has been observed that water use efficiency might be strongly correlated with variability of the global surface temperature due to increase of global $\mathrm{CO}_{2}$ emission. The analysis of the influence of variability of the global surface temperature due to the increase of global $\mathrm{CO}_{2}$ anthropogenic emissions on WUE will be a subject of future study.

\section{ACKNOWLEDGEMENTS}

The authors wish to express their gratitude to everyone who contributed to making these investigations possible. We would like to express thanks to Magdalena Opała from the University of Silesia (Katowice, Poland) for sampling and dating of wood. The research was a part of BIOPOL project "Trees as bioindicators of industrial air pollution during implementation of pro-environmental policy in the Silesia region" - funded by the National Science Centre allocated on the basis of the decision number DEC-2011/03/D/ST10/05251 (PI: B. Sensuła). This publication is supported under the grant rector in research and development of Silesian University of Technology, grant number 14/990/RGJ17/0077.

\section{REFERENCES}

Andersson E, 1965. Cone and seed studies in Norway spruce (Picea abies (L.) Karst). Studia Forestalia Suecica 23: 214pp.

Barbour MM, Walcroft AS and Farquhar GD, 2002. Seasonal variation in $\delta^{13} \mathrm{C}$ and $\delta^{18} \mathrm{O}$ of cellulose from growth rings of Pinusradiata. Plant, Cell and Environment 25: 1483-1499, DOI 10.1046/j.00168025.2002.00931.x.

Battipaglia G, Saurer M, Cherubini P, Calfapietra C, McCarthy HR, Norby RJ, Cotrufo FM, Boettger T, Haupt M, Friedrich M and Waterhouse JS, 2014. Reduced climate sensitivity of carbon, oxygen and hydrogen stable isotope ratios in tree-ring cellulose of silver fir (Abies alba Mill.) influenced by background $\mathrm{SO}_{2}$ in Franconia (Germany, central Europe). Environmental Pollution 185: 281-294, DOI 10.1016/j.envpol.2013.10.030.

Bigler Ch, Bräker OU, Bugmann H, Dobbertin M and Rigling A, 2006. Drought as an Inciting Mortality Factor in Scots Pine Stands of the Valais, Switzerland. Ecosystems 9: 330-343. DOI 10.1007/s10021-005-0126-2.

Boden TA, Marland G and Andres RJ, 2016. Global, Regional and National Fossil-Fuel $\mathrm{CO}_{2}$ Emissions. Carbon Dioxide Information Analysis Center, Oak Ridge National Laboratory, U.S. Department 
of Energy, Oak Ridge, Tenn., U.S.A. DOI 10.3334/CDIAC/00001 V2010.

Boettger T, Haupt M, Friedrich M and Waterhouse JS, 2014. Reduced climate sensitivity of carbon, oxygen and hydrogen stable isotope ratios in tree-ring cellulose of silver fir (Abies alba Mill.) influenced by background SO2 in Franconia (Germany, Central Europe). Environmental Pollution 1: 281-294, DOI 10.1016/j.envpol.2013.10.030.

Buchmann N, Brooks JR and Ehleringer JR, 2002. Predicting daytime carbon isotope ratios of atmospheric $\mathrm{CO}_{2}$ within forest canopies. Functional Ecology 16(1): 49-57, DOI 10.1046/j.02698463.2001.00591.x.

Burk RL and Stuiver M, 1981. Oxygen isotope ratios in trees reflect mean annual temperature and humidity. Science 211: 1417-1419, DOI 10.1126/science.211.4489.1417.

Carrer M and Urbinati C, 2004. Age-dependent tree-ring growth response to climate in Larix decidua and Pinus cembra. Ecology 85: 730-740, DOI 10.1890/02-0478.

Cedro A and Lamentowicz M, 2011. Contrasting responses to environmental changes by pine (Pinus sylvestris $\mathrm{L}$.) growing on peat and mineral soil: An example from a Polish Baltic bog. Dendrochronologia 29: 211-217, DOI 10.1016/j.dendro.2010.12.004.

Chałupka W, Giertych M and Królikowski Z, 1976. The effect of cone crops on growth in Scot pine on tree diameter increment. Arboretum Kórnickie 21: 361-366.

Cinnirella S, Magnani F, Saracino A and Borghetti M, 2002. Response of a mature Pinus laricio plantation to a three-year restriction of water supply: structural and functional acclimation to drought. Tree Physiology 22: 21-30.

Comstock JP and Ehleringer JR, 1992. Correlating genetic variation in carbon isotopic composition with complex climatic gradients. Proceedings of the National Academy of Science 89: 7747-7751, DOI 10.1073/pnas.89.16.7747.

Craig H, 1954. Carbon-13 in plants and the relationship between carbon-13 and carbon-14 variations in nature. Journal of Geology 62: 115-149.

Crecente-Campo F, Soares P, Tomé M and Diéguez-Aranda U, 2010. Modelling annual individual-tree growth and mortality of Scots pine with data obtained at irregular measurement intervals and containing missing observations. Forest Ecology and Management 260: 1965-1974, DOI 10.1016/j.foreco.2010.08.044.

Danek M, 2007. The influence of industry on scots pine stands in the south-eastern part of the Silesia-Kraków Upland (Poland) on the basis of dendrochronological analysis. Water, Air and Soil Pollution 18: 265-277, DOI 10.1007/s11270-007-9448-3.

Dauskane I, Brumelis G and Elferts D, 2011. Effects of climate and extreme radial growth of Scots pine growing on bogs in Latvia. Estonian Journal of Ecology 60(3): 236-248.

DeVries W, Klap JM and Erisman JW, 2000. Effects of environmental stress on forest crown condition in Europe. Part I: hypotheses and approach to the study. Water, Air and Soil Pollution 119: 317-333, DOI 10.1023/A:1005157509454.

Dongmann G, Nurnberg HW, Forstel H and Wagener K, 1974. On the enrichment of $\mathrm{H} 2{ }^{18} \mathrm{O}$ in leaves of transpiring plants. Radiation, Environment and Biophysiology.11:41-52.

Douglass AE, 1920. Evidence of climate effects in the annual rings of trees. Ecology 1: 24-32.

Ehleringer JR, 1990. Correlations between carbon isotope discrimination and leaf conductance to water vapor in common beans. Plant Physiology 93: 1422-1425, DOI 10.1104/pp.93.4.1422.

Ehleringer JR, Hall AE and Farquhar GD, 1993. (Eds.), Stable Isotope and Plant Carbon-Water Relations. Academic Press, New York, USA: $555 \mathrm{pp}$.

Ehrelinger J and Vogel J, 1993. Historical aspects of stable isotopes in plant carbon and water relations. In: Ehleringer JR, Hall AE and Farquhar GD, (eds).,Stable isotopes and plant carbon-water relations. New York: Academic Press: 9-19.

Eis S, Garman EH and Bell LF, 1965. Relation between cone production and diameter increment of Douglas fir (Pseudotsugamenziesii (Mirb.) Franco, grand fir (Abies grandis (Dougl.) Lindl.) and west- ern white pine (Pinus monticola Dougl.). Canadian Journal of Botany 43: 1553-1559.

Elling W, DittmarCh, Pfaffelmoser K and Rotzer T, 2009. Dendroecological assessment of the complex causes of decline and recovery of the growth of silver fir (Abies alba Mill.) in Southern Germany. Forest Ecology and Management 257(4): 1175-1187, DOI 10.1016/j.foreco.2008.10.014.

Epstein S and Yapp C, 1977. Isotope tree thermometers. Nature 266: 477-478, DOI 10.1038/266477a0.

Ermich K, 1959. Badania nad sezonowym przebiegiem przyrostu grubości pnia u Pinus silvestris L. i Quercus robur L. (The research on seasonal course of diameter growth $P$. silvestris and $Q$. robur). Acta Societatis Botanicorum Poloniae 28(1): 15-63 (in Polish).

Farquhar GD and Lloyd L, 1993. Carbon and oxygen isotope effects in the exchange of carbon dioxide between plants and the atmosphere. In: Ehleringer JR, Hall AE and Farquhar GD, (eds). Stable isotopes and plant carbon-water relations. New York, Academic Press:47-70.

Ferrio J, Voltas J and Araus J, 2003. Use of carbon isotope composition in monitoring environmental changes. Management of Environmental Quality 14: 82-98

Field CB, Jackson RB and Mooney HA, 1995. Stomatal responses to increased $\mathrm{CO}$ 2: implications from the plant to the global scale. Plant, Cell and Environment, 18: 1214-1225, DOI 10.1111/j.1365-3040.1995.tb00630.x.

Fober H, 1976. Relation between climatic factors and Scots pine (Pinussylvestris) cone crops in Poland. Arboretum Kórnickie 21: 367374

Friedrichs DA, Neuwirth B, Winiger M and Löffler J, 2009. Methodologically induced differences in oak site classifications in a homogeneous tree-ring network. Dendrochronologia 27: 21-30, DOI 10.1016/j.dendro.2008.02.001.

Fritts HC, 1976. Tree Rings and Climate. Academic Press, London: $567 \mathrm{pp}$.

Gagen M, Finsinger W, Wagner-Cremer F,McCarroll D, Loader N, Robertson I, Jalkanen R, Young G, and Kirchhefer A, 2011. Evidence of changing intrinsic water-use efficiency under rising atmospheric $\mathrm{CO} 2$ concentrations in Boreal Fennoscandia from subfossil leaves and tree ring d13C ratios. Global Change Biology 17: 1064-1072, DOI 10.1111/j.1365-2486.2010.02273.x.

Gray $\mathrm{J}$ and Thompson $\mathrm{P}, 1976$. Climatic information from ${ }^{18} \mathrm{O} /{ }^{16} \mathrm{O}$ ratios of cellulose in tree rings. Nature 262: 481-482, DOI $10.1038 / 262481 \mathrm{a} 0$

Green J, 1963. Wood cellulose. In: Whistler RL, (eds.), Methods in Carbohydrate Chemistry 3. Academic Press, New York: 9-21.

Gruber A, Strobi S, Veit B and Oberhuber W, 2010. Impact of drought on the temporal dynamics of wood formation in Pinus sylvestris. Tree Physiology 30(4): 490-501, DOI 10.1093/treephys/tpq003.

Hejnowicz A, 1982. Budowa i rozwój wegetatywnych pąków sosny zwyczajnej Pinus sylvestris L. (Structure and development of Scots pine vegetative bud). Instytut Dendrologii PAN, Kórnik: 97pp. (in Polish)

Helama S, Mielikäinen K, Timonen M, Herva $\mathrm{H}$, Tuomenvirta $\mathrm{H}$ and Veneäläinen A, 2013. Regional climatic signals in Scots pine growth with insights into snow and soil associations. Dendrobio$\operatorname{logy} 70$ : 27-34, DOI 10.12657/denbio.070.003.

Heres AM, Martínez-Vilalta J and López BC, 2012. Growth patterns in relation to drought-induced mortality at two Scots pine (Pinus sylvestris L.) sites in NE Iberian Peninsula. Trees 26(2): 621-630, DOI 10.1007/s00468-011-0628-9.

Herguido E, Granda E, Benavides R, García-Cervigón AI, Camarero JJ and Valladares F, 2016. Contrasting growth and mortality responses to climate warming of two pine species in a continental Mediterranean ecosystem. Forest Ecology and Management 363: 149-158, DOI 10.1016/j.foreco.2015.12.038.

Holmes RL and Lough JM, 1999. RESPO - Response and correlation function. Laboratory of Tree-Ring Research, Univ. of Arizona, Tucson.

Holmes RL, 1983. Computer-assisted quality control in tree-ring dating and measurement. Tree-Ring Bulletin 43: 69-78. 
IPCC, 2005. IPCC Special Report on Carbon Dioxide Capture and Storage. Prepared by Working Group III of the Intergovernmental Panel on Climate Change, Eds B. Metz, O. Davidson, H.C. de Coninck, M. Loos, and L.A. Meyer. Cambridge, Cambridge University Press, s. 442.

Irvine J, Perks MP, Magnani F and Grace J, 1998. The response of Pinus sylvestris to drought: stomatal control of transpiration and hydraulic conductance. Tree Physiology 18: 393-402.

Juknys R, Augustaitis A, Venclovienė J, Kliučius A, Vitas A, Bartkevičius E and Jurkonis N, 2014. Dynamic response of tree growth to changing environmental pollution. European Journal of Forest Research 133: 713-724, DOI 10.1007/s10342-013-0712-3.

Keeling RF, Piper SC, Bollenbacher AF and Walker SJ, 2010. Monthly atmospheric ${ }^{13} \mathrm{C} /{ }^{12} \mathrm{C}$ isotopic ratios for $11 \mathrm{SIO}$ stations. In Trends: A Compendium of Data on Global Change. Carbon Dioxide Information Analysis Center, Oak Ridge National Laboratory, U.S. Department of Energy, Oak Ridge, Tenn., U.S.A.

Kienast F, 1985. Tree ring analysis, forest damage and air pollution in the Swiss Rhone Valley. Land use Policy 2: 74-77.

Krapiec M and Szychowska-Krapiec E, 2001. Tree-ring estimation of the effect of industrial pollution on pine (Pinussylvestris) and fir (Abies alba) in the Ojców National Park (Southern Poland). Nature Conservation 58: 33-42.

Lindholm M, Meriläinen J, Timonen M, Vanninen P and Eronen M, 1997. Effects of climate on the growth of Scots pine in the Saimaa Lake District, South-Eastern Finland, in the southern part ofthe boreal forest belt. Dendrochronologia 15: 151-168.

Lindholm M, Timonen M and Meriläinen J, 1996. Extracting midsummer temperatures from ring-width chronologies of living pines at the northern forest limit in Fennoscandia. Dendrochronologia 14: $99-113$.

Lührte von A, 1991. Dendroökologische Untersuchungen an Kiefern und Eichen in den standnahen Berliner Forsten (Dendroecological studies of pine and oak trees in the stand near Berlin forests). Landschaftsentwicklung und Umweltforschung. Schriftenreihe des Fachbereichs Landschaftsentwicklung der TU Berlin: 186pp. (in German).

Major JE and Johnsen KH, 2001. Shoot water relations of mature black spruce families displaying a genotype $\times$ environment interaction in growth rate. III. Diurnal patterns as influenced by vapour pressure deficit and internal water status. Tree Physiolgy 21: 579-587.

Malik I, Danek M, Marchwińska-Wyrwał E, Danek T, Wistuba M and Krąpiec M, 2012. Scots pine (Pinussylvestris L.) growth suppression and adverse effects on human health due to air pollution in the Upper Silesian Industrial District (USID), Southern Poland. Water, Air and Soil Pollution 223: 3345-3364, DOI 10.1007/s11270-0121114-8.

Marqués L, Camarero JJ, Gazol A and Zavala MA, 2016. Drought impacts on tree growth of two pine species along an altitudinal gradient and their use as early-warning signals of potential shifts in tree species distributions. Forest Ecology and Management 381(1): 157-167, DOI 10.1016/j.foreco.2016.09.021.

Martin B, Bytnerowicz A and Thorstenson YR, 1988. Effects of air pollutants on the composition of stable carbon isotopes, $\delta^{13} \mathrm{C}$, of leaves and wood, and on leaf injury. Plant Physiology 88: 218223, DOI 10.1104/pp.88.1.218.

McCarroll D and Loader NJ, 2004. Stable isotopes in tree rings. Quaternary Science Reviews 23: 771-801, DOI 10.1016/j.quascirev.2003.06.017.

McCarroll D, Gagen MH, Loader NJ, Robertson I, Anchukaitis KJ, Los S, Young G, Jalkanen R, Kirchhefer A and Waterhouse JS, 2009. Correction of tree ring stable carbon isotope chronologies for changes in the carbon dioxide content of the atmosphere. Geochimica et Cosmochimica Acta 73(6):1539-1547, DOI 10.1016/j.gca.2008.11.041.

Morgan JA, Mosier AR, Milchunas DG, LeCain DR, Nelson JA, 2004. $\mathrm{CO} 2$ enhances productivity, alters species composition, and reduces digestibility of shortgrass steppe vegetation. Ecological Applications 14: 208-219, DOI 10.1890/02-5213.
Morison JIL, 1993. Response of plants to CO2 under water limited conditions. Vegetatio 104-105:193-209, DOI 10.1007/BF00048153.

NASA, 2016. Web site: <http://climate.nasa.gov/vital-signs/carbondioxide/>, Accessed 2016 May.

NOAA, 2016.2 Web site: $<$ https://www.esrl.noaa.gov/gmd/ccgg/trends/>, Accessed 2016 May.

Parn $\mathrm{H}$ and Mandre M, 2011. Dendrochronological analysis of the growth and growth-climate relationships of conifers in the region of alkaline dust deposition. Forest Ecology and Management 262(2): 88-94, DOI 10.1016/j.foreco.2010.06.019.

Pazdur A, Kuc T, Pawełczyk S, PiotrowskaN, Sensuła BM and Różański K, 2013. Carbon Isotope Composition of Atmospheric Carbon Dioxide in Southern Poland: Imprint of Anthropogenic CO2 Emissions in Regional Biosphere. Radiocarbon 55(2-3): 848-864.

Pazdur A, Nakamura T, Pawełczyk S, Pawlyta J, Piotrowska N, Rakowski A, Sensuła B and Szczepanek M, 2007. Carbon isotopes in tree rings: climate and human activities in the last 400 years. Radiocarbon 49(2): 1133-1143.

Pensa M, Salminen H and Jalkanen R, 2005. A 250-year-long heightincrement chronology for Pinussylvestris at the northern coniferous timberline: A novel tool for reconstructing past summer temperatures? Dendrochronologia 22: 75-81.

Pichler P and Oberhuber W, 2007. Radial growth response of coniferous forest trees in an inner Alpine environment to heat-wave in 2003. Forest Ecology and Management 242: 688-699, DOI 10.1016/j.foreco.2007.02.007.

Piovesan G, Biondi F, Di Filippo A, Alessandrini A and Maugeri M, 2008. Drought-driven growth reduction in old beech (Fagus sylvatica $\mathrm{L}$.) forests of the central Apennines, Italy. Global Change Biology 14: 1265-1281, DOI 10.1111/j.1365-2486.2008.01570.x.

Richter K, Eckstein D and Holmes RL, 1991. The dendrochronological signal of pine trees (Pinus spp.) in Spain. Tree-Ring Bulletin 51: $1-13$.

Rinne KT, Loader NJ, Switsur VR, Treydte KS and WaterhouseJS, 2010. Investigating the influence of sulphur dioxide $\left(\mathrm{SO}_{2}\right)$ on the stable isotope ratios $\left(\delta^{13} \mathrm{C}\right.$ and $\left.\delta^{18} \mathrm{O}\right)$ of tree rings. Geochimica et Cosmochimica Acta 74: 2327-2339, DOI 10.1016/j.gca.2010.01.021

Roden J, Lin G, Ehleringer J, 2000. A mechanistic model for the interpretation of hydrogen and oxygen isotope ratios in tree-ring cellulose. Geochimica et Cosmochimica Acta 64: 21-35, DOI 10.1016/S0016-7037(99)00195-7.

Saurer M, Aellen K and Siegwolf R, 1997. Correlating $\delta 13 \mathrm{C}$ and $\delta 18 \mathrm{O}$ in cellulose of trees. Plant, Cell and Environment 20: 1543-1550, DOI 10.1046/j.1365-3040.1997.d01-53.x.

Saurer M and Siegwolf RTW, 2007. Human impacts on tree-ring growth reconstructed from stable isotopes. In: Dawson TE and Siegwolf RTW, eds., Stable isotopes as indicators of ecological change terrestrial ecology series. Elsevier: Amsterdam: 49-62.

Saurer M, Spahni R, Frank DC, Joos F, Leuenberger M, Loader NJ, McCarroll D,Gagen M,Poulter B,Siegwolf RW, Andreu-Hayles L, Boettger T,Linan ID, Fairchild IJ, Friedrich M, Gutierrez S,Haupt M, Hilasvuori E, Heinrich I, Helle G, Grudd H, Jalkanen R, Levanic T, Linderholm HW, Robertson I, Sonninen E, Treydte K, Waterhouse JS, Woodley EJ, Wynn PM and Young GHF, 2014. Spatial variability and temporal trends in water-use efficiency of European forests. Global Change Biology 20: 3700-3712, DOI 10.1111/gcb.12717.

Savard MM, 2010. Tree-ring stable isotopes and historical perspectives on pollution - an overview. Environmental Pollution 158: 20072013, DOI 10.1016/j.envpol.2009.11.031.

Scheidegger Y, Saurer M, Bahn M and Siegwolf R, 2000. Linking stable oxygen and carbon isotopes with stomatal conductance and photosynthetic capacity: a conceptual model. Oecologia 125: 350 357, DOI 10.1007/s004420000466.

Schiegl WE, 1974. Climatic significance of deuterium abundance in growth rings of Picea. Nature 251: 582-584, DOI $10.1038 / 251582 \mathrm{a} 0$ 
Schober R, 1951. Zum jahreszeitlischen Ablauf des sekundären Dickenwachstums (Forseasonalflowofsecondarygrowth). Allgemeine Forst- und Jagdzeitung 122: 81-96 (in Germany).

Schweingruber FH, 1986. Abrupt growthchanges in conifers. IAWA Bulletin 7(4): 277-283.

Schweingruber FH, 1996. Tree Rings and Environment. Dendroecology. Swiss Federal Institute for Forest, Snow and Landscape Research, and Paul HauptVerlag: 609pp.

Sensuła B, 2016a. $\delta^{13} \mathrm{C}$ and water use efficiency in the glucose of annual pine tree-rings as ecological indicators of the forests in the most industrialized part of Poland. Water, Air, and Soil Pollution 227(2): 68, DOI 10.1007/s11270-016-2750-1.

Sensuła B, 2016b. The Impact of Climate, Sulfur Dioxide, and Industrial Dust on $\delta^{18} \mathrm{O}$ and $\delta^{13} \mathrm{C}$ in Glucose from Pine Tree Rings Growing in an Industrialized Area in the Southern Part of Poland. $\mathrm{Wa}$ ter, Air, and Soil Pollution 227(4): 106, DOI 10.1007/s11270-0162808-0.

Sensuła BM, Pazdur A, Bickerton J and Derrick PJ, 2011a. Probing palaeoclimatology through quantitation by mass spectrometry of the products of enzyme hydrolysis of $\alpha$-cellulose. Cellulose 18(2): 461-468, DOI 10.1007/s10570-010-9490-y.

Sensuła B, 2015. Spatial and Short-Temporal Variability of $\delta^{13} \mathrm{C}$ and $\delta^{15} \mathrm{~N}$ and Water-Use Efficiency in Pine Needles of the Three Forests Along the Most Industrialized Part of Poland. Water, Air, and Soil Pollution 226: 362, DOI 10.1007/s11270-015-2623-z.

Sensuła B, Opała M, Wilczyński S and Pawełczyk S, 2015a. Long-and short-term incremental response of Pinus sylvestris L. from industrial area nearby steelworks in Silesian Upland, Poland. Dendrochronologia 36: 1-12, DOI 10.1016/j.dendro.2015.08.001.

Sensuła B and Pazdur A, 2013a. Influence of climate change on carbon and oxygen isotope fractionation factors between glucose and $\alpha$ cellulose of pine wood. Geochronometria 40(2): 145-152, DOI 10.2478/s13386-013-0104-y.

Sensuła B and Pazdur A, 2013b. Stable carbon isotopes of glucose received from pine tree-rings as bioindicators of local industrial emission of $\mathrm{CO}_{2}$ in Niepołomice Forest (1950-2000). Isotopes in Environmental and Health Studies 49(4): 532-541, DOI 10.1080/10256016.2013.865026.

Sensuła BM, Pazdur A and Marais MF, 2011b. First application of mass spectrometry and gas chromatography in investigation of $\alpha$ cellulose hydrolysates: the influence of climate changes on glucose molecules in pine tree-rings. Rapid Communications in Mass Spectrometry 25(4): 489-494, DOI 10.1002/rcm.4882.

Sensuła B, Wilczyński S, Monin L, Mohammed A, Pazdur A, Fagel N, 2017. Variations of tree ring width and chemical composition of wood of pine growing in the area nearby chemical factories. Geochronometria 44: 226-239, DOI 10.1515/geochr-2015-0064.
Sensuła B, Wilczyński S and Opała M, 2015b. Tree growth and climate relationship: Dynamics of Scots pine (Pinussylvestris L.) growing in the near-source region of the combined heat and power plant during the development of the pro-ecological strategy in Poland. Water, Air, and Soil Pollution 226: 220, DOI 10.1007/s11270-015$2477-4$.

StatSoft, Inc, 2014. STATISTICA (data analysis software system), version 12. www.statsoft.com.

Stips A, Macias D, Coughlan C, Garcia-Gorriz E and Liang XS, 2016. On the causal structure between $\mathrm{CO} 2$ and global temperature. Scientific Reports 6: 21691, DOI 10.1038/srep21691.

Tuovinen M, 2005. Response of tree-ring width and density of Pinus sylvestris to climate beyond the continuous northern forest line in Finland. Dendrochronologia 22: 83-91.

Vaganov EA, 1990. The tracheidogram method in tree-ring analysis and its application. In: Cook ER and Kairiukstis LA, eds., Methods of Dendrochronology. Kluwer Academic Publication. Dodrecht, Boston, London: 63-76.

Wigley TML, Briffa KR and Jones PD, 1984. On the Average Value of Correlated Time Series. with Applications in Dendroclimatology and Hydrometeorology. Journal of Applied Meteorology and Climatology 23: 201-213, DOI 10.1175/15200450(1984)023<0201:OTAVOC >2.0.CO;2.

Wilczyński S and Skrzyszewski J, 2003. Dendrochronology of Scots pine (Pinus sylvestris L.) in the mountains of Poland. Journal of Forest Science 49(3): 95-103.

Wilczyński S, 2003. Modele klimat-przyrost radialny sosen z Tatr, Pienin i Ojcowa (Models of climate-radial growth of pines from Tatra, Pieniny and Ojców). Sylwan 147(12): 27-35 (in Polish).

Wilczyński S, 2006. The variation of tree-ring widths of Scots pine (Pinus sylvestris L.) affected by air pollution. European Journal of Forest Research 125: 213-219, DOI 10.1007/s10342-005-0106-2.

Wilczyński S, 2013. Przyczyny krótkookresowych reakcji przyrostowych sosen z różnych siedlisk (Reasons for short-term incremental response pines from different habitats). Sylwan 157(9): 662-670 (in Polish).

Wodzicki TJ and Zajączkowski S, 1983. Variation of seasonal cambial activity and xylem differentiation in a selected population of Pinus sylvestris L. Folia Forestalia Polonica Series A 25: 5-23.

Yoder BJ, Ryan MG, Waring RH, Schoettle AW and Kaufmann MR, 1994. Evidence of reduced photosynthetic rates in old trees. Forest Science 40: 513-527.

Yu G, Liu Y and Wang X, 2008. Age-dependent tree-ring growth responses to climate in Qilian juniper (Sabina przewalskii Kom.). Trees 22: 197-204, DOI 10.1007/s00468-007-0170-y. 